NBER WORKING PAPER SERIES

\title{
ASPIRATIONS AND FINANCIAL DECISIONS: EXPERIMENTAL EVIDENCE FROM THE PHILIPPINES
}

\author{
David McKenzie \\ Aakash Mohpal \\ Dean Yang \\ Working Paper 28607 \\ http://www.nber.org/papers/w28607 \\ NATIONAL BUREAU OF ECONOMIC RESEARCH \\ 1050 Massachusetts Avenue \\ Cambridge, MA 02138 \\ March 2021, Revised August 2021
}

We are thankful to the staff of People's Alternative Foundation of Sorsogon, Inc. (PALSFI) and CEO Sr. Adelia Oling for collaborating in this research, and to Innovations for Poverty Action (IPA), Philippines for coordinating fieldwork. We are grateful to Innovations for Poverty Action and the World Bank's Research Support Budget (RSB) for funding this research. Matthew Groh and Jose Marie Gonzalez provided excellent research assistance. We obtained IRB approval from the Innovations for Poverty Action IRB (12September-003). The findings, interpretations, and conclusions expressed in this paper are those of the authors. They do not necessarily represent the views of the institutions they are affiliated with. Our AEA RCT Registry number is AEARCTR-0000148. The views expressed herein are those of the authors and do not necessarily reflect the views of the National Bureau of Economic Research.

NBER working papers are circulated for discussion and comment purposes. They have not been peer-reviewed or been subject to the review by the NBER Board of Directors that accompanies official NBER publications.

(C) 2021 by David McKenzie, Aakash Mohpal, and Dean Yang. All rights reserved. Short sections of text, not to exceed two paragraphs, may be quoted without explicit permission provided that full credit, including $\odot$ notice, is given to the source. 
Aspirations and Financial Decisions: Experimental Evidence from the Philippines

David McKenzie, Aakash Mohpal, and Dean Yang

NBER Working Paper No. 28607

March 2021, Revised August 2021

JEL No. D14,G53,O12

\section{ABSTRACT}

A randomized experiment among poor entrepreneurs tested the impact of exogenously inducing higher financial aspirations. In theory, raising aspirations could have positive effects by inducing higher effort, but could also reduce effort if unmet aspirations lead to frustration. Treatment resulted in more ambitious savings goals, but nearly all individuals fell far short of reaching these goals. Two years later, treated individuals had not saved more, and actually had lower borrowing and business investments. Treatment also reduced belief in the amount of control over one's life. Setting aspirations too high can lead to frustration, leading individuals to reduce their economic investments.

David McKenzie

The World Bank, MSN MC3-307

1818 H Street N.W.

Washington, DC 20433

dmckenzie@worldbank.org

Aakash Mohpal

The World Bank, MSN I7-700

1818 H Street N.W.

Washington, DC 20433

amohpal@worldbank.org
Dean Yang

University of Michigan

Department of Economics and

Gerald R. Ford School of Public Policy

735 S. State Street, Room 3316

Ann Arbor, MI 48109

and NBER

deanyang@umich.edu 


\section{Introduction}

Can raising the aspirations of the poor help them escape poverty? Theoretically, sub-optimally low aspirations could arise through a behavioral bias (Dalton et al., 2016). Aspirations spur individuals to work harder, but when determining their effort level, people fail to account for how realized outcomes will affect future aspirations and hence future effort. This "aspirations failure" may cause a behavioral poverty trap: poverty begets lower aspirations, which keeps individuals in poverty. In the absence of other binding constraints, simply inducing the poor to set higher aspirations can help them break out of the poverty trap. This "mindset" approach has been the focus of bestselling financial self-help books such as Secrets of the Millionaire Mind (Eker, 2005) and Rich Dad, Poor Dad (Kiyosaki, 2017). In the developing country context, Ray (1998) was first to highlight the potential for poverty traps due to sub-optimally low aspirations (see also Appadurai (2004), Ray (2006), Duflo (2012) and Lybbert and Wydick (2018)).

There is, however, a potential downside to encouraging higher aspirations. If aspirations are set too high, individuals may fail to reach their goals, and become frustrated. This frustration could lead people to reduce their economic investments (Genicot \& Ray, 2017, 2020). Furthermore, frustration could have lasting negative consequences if it affects consequential psychological factors, such as the perceived ability to control one's life outcomes.

We conducted a randomized experiment with over 2,400 small-scale entrepreneurs, who were clients of a microfinance institution in the Philippines, to study how raising aspirations affects financial decision-making and outcomes. The financial aspirations treatment was implemented with microcredit borrowing groups in eight weekly sessions. It encouraged participants to set ambitious life goals, and choose savings targets associated with those goals. We also crossrandomized a "knowledge" treatment that provided financial education about savings, budgeting, and planning. This enables benchmarking the impact of the aspirations treatment against impacts of a more traditional intervention in the microfinance context.

We measure impacts of the aspirations and knowledge treatments with a survey two years later, alongside administrative microfinance institution data. We find the aspirations treatment leads individuals to set higher savings goals. However, individuals achieve only small fractions (on average $5 \%$ ) of their savings goals, and the aspirations treatment does not increase savings. Instead, the aspirations treatment leads to less borrowing (a 15\% reduction in debt) and business investment (a 37\% reduction). The finding of zero impact on savings and reductions in borrowing is consistent across self-reported survey outcomes and administrative data. These results provide evidence for the theorized possibility of Genicot \& Ray $(2017,2020)$ that if aspirations are set too high, they could lead to frustration and reductions in economic investments. We also find an additional mechanism not included in their model: the survey data reveals a reduction in respondents' beliefs 
that they are in control of their own life outcomes, as measured by an index of internal locus of control. $^{4}$

Our paper is related to several studies of the impact of raising aspirations on poverty. Prior research has shown that inducing higher aspirations can positively affect educational investments (Beaman et al., 2012; Bernard et al., 2018; Carlana et al., forthcoming; Clark et al., 2019; Mukherjee, 2017; Riley, 2020), and induce savings and productive investments (Lybbert \& Wydick, 2016; Macours \& Vakis, 2014; Seshan \& Yang, 2014). Related research studies self-efficacy and self-image (Ghosal et al., 2020; McKelway, 2021).

Relative to this literature, our paper has several distinguishing features. First, ours is one of the few studies of an intervention explicitly aimed at raising aspirations to influence financial decisionmaking regarding savings and credit. ${ }^{5}$ Second, we provide empirical confirmation of a "frustration" effect from increasing aspirations, which can lead to reduced economic investment. ${ }^{6}$ Finally, our results reveal an additional mechanism through which a failure to reach aspirations may have enduring consequences on financial decision-making, even after aspirations may have returned to their original levels: a reduction in internal locus of control. If people respond to the experience of trying and failing to reach high aspirations by believing that they have less control over their own lives, this may change their future financial decision-making, potentially for the worse.

Our work is also related to the literature on locus of control (Judge et al., 2002; Rotter, 1954, 1966). Internal locus of control is positively associated with many economic outcomes, such as labor market performance and financial decision-making (Cobb-Clark, 2014; Ng et al., 2006; Salamanca et al., 2020). Other studies have found that locus of control is a pliable individual characteristic. Randomized treatments have been found to increase internal locus of control (Gottschalk, 2005; Pederson et al., 2015), while negative shocks in early life lead to lower internal locus of control in adulthood (Shoji, 2020). Relative to this literature, our contribution is to show that well-meaning interventions (such as the aspirations treatment we study) can inadvertently lead people to have less internal locus of control, with potential consequences for future financial decision-making.

This paper also contributes to a large literature on financial literacy. Poor financial knowledge is argued to be a key barrier to savings (Brown \& Gartner, 2007; Lusardi, 2001), but research examining the impacts of financial literacy training alone has found mixed impacts on financial behaviors (Fernandes et al., 2014; Knowles, 2018). On the other hand, training combined with monetary incentives and subsidies have been shown to increase take-up and utilization of savings products (Cole et al., 2011). Some studies also combined financial education with goal setting and

\footnotetext{
${ }^{4}$ The knowledge treatment, on the other hand, has little impact on most of the outcomes examined, and we find little evidence of interactions between the two treatments.

${ }^{5}$ Bernard et al. (2018) find that a randomly-assigned aspiration treatment in Ethiopia raises savings and borrowing.

${ }^{6}$ Galiani et al. (2018) find that exogenously raising aspirations does not affect housing investment; they do not, however, find reductions in investments, as we do. In non-experimental data, Janzen et al. (2017) and Ross (2019) find a U-shaped relationship between aspirations and investment.
} 
personalized financial counseling, and found significant impacts on real financial outcomes (Carpena et al., 2019). Our study tests the approach of trying to increase financial aspirations and compares it to the traditional financial education approach of improving financial knowledge.

\section{Intervention and Experimental Design}

\subsection{Study setting and partner institution}

Our study takes place in Sorsogon province, Philippines. Our partner institution, Peoples' Alternative Livelihood Foundation of Sorsogon, Inc. (PALFSI), is a microfinance institution that operates throughout the province. It offers savings accounts and group-based microfinance loans to a client base mostly consisting of female subsistence entrepreneurs. Typical businesses are raising livestock; small retail businesses selling items such as baked goods, fish, or sodas; tricycle and boat rentals; hair dressing; and reselling scrap metal. Loans are typically one year in duration, with borrowers paying $2 \%$ fixed interest on the initial value of the loan each month throughout the duration of the loan. ${ }^{7}$

For every new loan, $4 \%$ of the total value is withheld and deposited in a compulsory savings account, which the client can only access on graduation from PALFSI's microcredit services. In addition, clients have access to a voluntary savings account that offers a $5 \%$ annual interest rate vested quarterly conditional on maintaining a 500 pesos balance. Before this savings account, clients had no formal access to free, flexible savings accounts. At baseline in 2012, take up of this product was low, with $43 \%$ of clients having 0 dollars in savings, $31 \%$ between 0 and $\$ 2.50$ (105.5 pesos), and $26 \%$ had more than $\$ 2.50$ in savings. ${ }^{8}$

We designed and initiated this study in 2012, in collaboration with PALFSI. That was some years before the emergence of the norm to prepare pre-analysis plans (PAPs) for randomized controlled trials, so we do not have a PAP for this study. That said, the main outcomes we examine - savings and loans - were unambiguously of central interest to PALFSI from the outset. All clients of PALFSI are borrowers by definition, and the project occurred in a period when PALFSI was seeking to raise clients' use of their new savings products.

\subsection{Treatment assignment}

Our sample consists of PALFSI's universe of 3,757 clients, who belong to 190 microcredit borrowing groups, ranging in size from 6 to 47 members. We stratified these groups by: (i) PALFSI's three branch locations; (ii) whether the group had more than 16 members $(57 \% \mathrm{did})$; and (iii) whether the group had $80 \%$ or more of its members with voluntary savings balances of 100 pesos $(\$ 2.37)$ or less $(59 \%$ did). Out of these 12 potential strata, one was empty. Groups were

\footnotetext{
${ }^{7}$ This is equivalent to a $48 \%$ APR since the principal is paid back in weekly installments over the year.

${ }^{8}$ For all currency conversions, we use the average nominal exchange rate for the year 2012, US $\$ 1=42.2$ Philippine pesos.
} 
then randomly assigned by computer within each stratum using a $2 \times 2$ design into a control group or one of three treatment groups - aspirations training only (T1), knowledge training only (T2), or both aspirations and knowledge training (T3).

Before launching the intervention and randomization, we conducted a short baseline survey collecting self-reported savings (in PALFSI and other institutions), follow-up contact information, and basic demographics. The 2,593 clients from 190 groups who completed the baseline survey are the sample of interest for this experiment. Randomization resulted in 48 groups in T1, 48 in T2, 48 in T3, and 46 in control (Appendix Figure A1). We were then able to re-interview 94.7\% of these (2,464 clients) in a follow-up survey two years later. Sample attrition is uncorrelated with treatment status. ${ }^{9}$ We use this sample of 2,464 clients for all analyses: 586 in T1, 618 in T2, 634 in T3, and 626 in control.

\subsection{Baseline characteristics and balance tests}

We present summary statistics and tests of balance with respect to treatment assignment in Appendix Table A1. 92\% of the participants in the control group were female and they were on average 47.1 years old. $81 \%$ are married, and $56 \%$ have high school education or above. The average client in the control group reported having 8,320 pesos in savings (\$197). This represents $7.3 \%$ of GDP per capita of $\$ 2,694$ in 2012 (World Bank, 2020). Almost $60 \%$ of savings are held in PALSFI accounts. $38.7 \%$ of the clients said that they made weekly deposits. Across all variables in Appendix Table A1, means in treatment groups are not statistically different from the control group means, with the exception of client gender: those in the knowledge group are statistically significantly more likely to be female (by 2.6 percentage points). This is roughly what would be expected to happen by chance. Overall, randomization appears to have succeeded in achieving balance with respect to baseline observables.

\subsection{Treatment contents and delivery}

The two treatments were designed by PlaNet Finance, an international non-profit organization working to develop the microfinance sector that operates in over 60 countries. Each treatment consisted of eight one-hour sessions. Here we summarize the contents of each treatment and provide further details in Appendix II.

The aspirations treatment sought to encourage and inspire clients to develop a long-term approach to personal and business finance. It used games to build self-confidence and exercises to help participants articulate long-term aspirations and define intermediate steps to reaching those aspirations. The first session helped participants identify obstacles to savings and empowered them to overcome these obstacles. The next two sessions asked participants to define their dreams and the steps required to reach these dreams. The fourth session introduced participants to the famous marshmallow experiment (Mischel \& Ebbesen, 1970), to highlight the importance of delaying

\footnotetext{
${ }_{9}^{9}$ Appendix Table A1, Panel A.
} 
gratification to achieve future rewards. The next three sessions reviewed concepts from prior sessions, and asked participants to reflect on and express the motivations behind their dreams. Finally, the last session emphasized positive thinking and "thinking rich". The training specifically focused on getting participants to dream and set big goals. Exhibit A1 in Appendix II provides an example of a presentation slide used in the training - participants were told that if dreams are too small, one will only see barriers, but a big dream will overcome barriers.

The knowledge treatment aimed to teach participants the financial skills needed to make savings and loan decisions. It emphasized learning about assets, liabilities, budgeting, and life-cycle planning. The first session introduced clients to assets and liabilities to prepare them for the second session on assessing net worth. The third session reviewed simple savings and interest rates calculations ("what happens if you save 1 dollar a day for 5 years and what happens if you save using a bank account instead of your piggy bank?”). The fourth session focused on saving in advance for retirement. The fifth session extended the retirement planning course to life events including weddings and college education. This was followed by two sessions on budgeting, and a final overview session putting budgeting and savings together.

To maximize participation and integrate trainings into clients' interactions with PALFSI, the training sessions were conducted at every fourth weekly meeting of borrowing groups. PlaNet Finance, together with World Bank and Innovations for Poverty Action staff, trained PALSFI's 19 loan officers, who then conducted trainings for their own groups. The aspirations module started in November 2012 and concluded in August 2013. The knowledge module started in June 2013 and concluded in December 2013. Appendix Figure A2 presents the study and intervention timeline.

\section{Intervention Take-up, Data and Empirical Strategy 3.1 Take-up of the interventions}

Take-up of the interventions was high. In T1 (aspirations only), 95\% of clients attended at least one session, with a mean of $73 \%$ of sessions and median of seven out of eight sessions. $30 \%$ of clients attended all sessions. In T2 (knowledge only), 80\% attended at least one session, with a mean of $64 \%$ of sessions and median of seven out of eight sessions, and $36 \%$ attending all sessions. Clients in the third treatment group (both aspirations and knowledge treatments) attended a median of 11 out of 16 sessions, with $93 \%$ attending at least one aspirations training session, and $79 \%$ at least one knowledge training session, and a mean attendance rate of $64 \%$ of all sessions. $13 \%$ in this group attended all 16 sessions. ${ }^{10}$

The fact that the treatment sessions were held during regular PALFSI group meetings likely contributed to high attendance rates, especially relative to many standalone financial education programs (Ibarra et al., 2019). Attendance rates are comparable to business training attendance

\footnotetext{
${ }^{10}$ Appendix Figure A3 shows attendance by session.
} 
rates when training was provided by microfinance credit officers: $71 \%$ in Field, et al. (2010), 50\% in Giné and Mansuri (2020) and 76-88\% in Karlan and Valdivia (2011).

\subsection{Survey and administrative data}

The primary outcomes of this study are savings and loan balances of study participants. We use both self-reported outcomes from our endline survey, as well as administrative outcomes from PALFSI's financial records. The outcomes from administrative data are important to rule out possible reporting biases (experimenter demand effects) in survey data. ${ }^{11}$ The survey data provide insights into savings and borrowing from institutions other than PALFSI, helping to check whether any changes in these outcomes at PALFSI reflect shifting of financial activity to and from other institutions (we find no evidence of such shifting).

The administrative data come from PALFSI's electronic financial accounting system and are processed to measure average savings and loan balances during time periods relevant for the study. The correlation between the savings account balance in the administrative data and in our selfreported survey data is nearly one (summary statistics reported in Table 2 and Appendix Table A1).

We fielded our endline survey from May to September 2015, approximately two years after the end of the intervention. The survey collected detailed data on savings goals, financial knowledge, savings and borrowing (at PALFSI and other institutions), business activity, and household expenditures and assets. We also collected information on time preference and locus of control. The survey was fielded to all 2,593 clients who had valid baseline data, with a completion rate of $94.7 \%$.

\subsection{Empirical Specification}

We estimate intention-to-treat (ITT) effects by estimating the following regression equation:

$$
\mathrm{y}_{\mathrm{ij}}=\alpha_{1}+\beta_{1} \cdot \mathbb{I}\{\mathrm{T} 1=1 \text { or } \mathrm{T} 3=1\}_{\mathrm{ij}}+\beta_{2} \cdot \mathbb{I}\{\mathrm{T} 2=1 \text { or } \mathrm{T} 3=1\}_{\mathrm{ij}}+\delta_{\mathrm{s}}+\epsilon_{\mathrm{ij}}
$$

where $\mathrm{y}_{i j}$ denotes the outcome of interest for client $\mathrm{i}$ in group $\mathrm{j} . \mathbb{I}(\cdot)$ denotes an indicator function that takes a value of 1 if the condition is satisfied, 0 otherwise. We include fixed effects for the eleven stratification cells $\left(\delta_{\mathrm{s}}\right)$ in all regressions. $\epsilon_{\mathrm{ij}}$ is the individual error term. Standard errors are clustered at the group level. To account for multiple hypothesis testing, we also report sharpened q-values following Anderson (2008).

This specification maximizes statistical power by using what Muralidharan, et al. (2021) refer to as the "short model". $\beta_{1}$ and $\beta_{2}$ give the effects of being offered the aspirations and knowledge

\footnotetext{
${ }^{11}$ We will see that findings are very similar across survey-reported and administrative outcomes, suggesting that reporting biases in the survey data are not significant in this context.
} 
treatments (respectively) in a sample in which half the individuals have also been offered the other treatment. We are underpowered to detect interaction effects ${ }^{12}$, but Appendix I reports results from the "long model" in which separate indicators are included for each treatment.

\section{Empirical Results}

\subsection{Impacts on Retention of Training Concepts and Savings Goals}

We begin by examining participants' retention of concepts taught in the training. We fielded the endline survey two years after the interventions, so the impacts we measure are those that persist over this timeframe. We are therefore capturing lasting impacts, rather than immediate recall right after training.

We asked participants questions on material covered in the two treatments and calculate the percentage of correct responses (the full list of these questions is in Appendix III). We do this separately for questions related to the aspirations treatment (e.g., definitions of limiting beliefs and dream timelines) and those related to the knowledge treatment (e.g., definitions of assets, liabilities, and net worth).

We estimate equation (1) for these outcomes and report results in Table 1, Panel A. Each treatment did lead to retention of concepts related to the training. The aspirations treatment leads to 1.99 percentage points higher share of correct responses on the aspirations questions, representing a $9 \%$ improvement relative to the control mean. The knowledge treatment raises the share of correct responses on the knowledge questions by 3.1 percentage points, an $8 \%$ improvement over the control mean. As one should expect, the aspirations treatment does not raise correct responses to the knowledge questions, and vice versa. These results are significant after multiple hypothesis testing (MHT) adjustments.

We turn to examining impacts on savings goals in Panel B. The aspirations treatment specifically focused on getting participants to "dream" and set more ambitious savings goals. The knowledgebased treatment emphasized the importance of planning for the future and considering future needs such as saving for children's education, which could also lead to changes in respondents' financial goals. We find that the aspirations treatment led to higher savings goals, and higher goals specifically for education. Education is the most frequently mentioned savings goal, accounting for more than half of stated goals in money terms. The coefficient on the aspirations indicator is positive and large in magnitude for both outcomes, and statistically significantly different from zero at the 5\% level for education savings goals. Savings goals as a share of household income are also higher among individuals assigned to the aspirations treatment (significant at the $10 \%$ level). Both these coefficients are also statistically significant at the $10 \%$ level after MHT adjustments.

\footnotetext{
${ }^{12}$ We designed the study before knowing exactly how much lower power is for detecting interactions than main effects (Gelman, 2018; Muralidharan, et al., 2021)
} 
By contrast, there is no large or statistically significant impact of the knowledge treatment on these savings goal outcomes.

These savings goal outcomes were measured roughly two years after treatment. Respondents could have changed their aspirations by the time we surveyed them, compared to their aspirations immediately after treatment, two years before. We did not collect information about savings goals immediately after the treatment, so we cannot comment on the dynamics of the treatment effect on goals over time. But the results we discuss next suggest that these goals measured two years after treatment might be lower than the goals respondents originally set right after treatment. We will return to this point at the end of Section 4.2.

Next, we ask if individuals were indeed successful in meeting their savings goals. We find that study participants fell far short of meeting their savings goals (Panel C). The average fraction of savings goal met in the control group is 0.050 , and the average fraction of education savings goal met is 0.017 . The results show that neither treatment had a meaningful impact on meeting these goals. Low achievement of goals, and the negligible impact of treatments on goal achievement, can also be seen in histograms of the distribution of savings goal met by treatment status (Figure 1). The distributions are very similar, and all have a significant probability mass at zero.

\subsection{Impact on Financial Outcomes}

The aspirations treatment led individuals to set more ambitious savings goals, so we now examine impacts on the primary financial outcomes: savings and borrowing. Panel A of Table 2 reports treatment effects on savings balances, and Panel B on loan balances. The endline survey collected detailed loan and saving information for all accounts held at PALSFI, other banks and microfinance institutions, ROSCAs, money lenders, and with informal sources such as family members and friends. From these survey responses, we calculate study participants' savings and loan balances (the latter variable is the total remaining unpaid balance of loans outstanding). We also construct corresponding savings and loan balance outcomes from PALFSI's administrative data for the same individuals, on average for the 4 months during which the endline survey was fielded (May to August 2015), so that the survey and administrative data refer to the same time period.

Individuals in the control group report having 7,424 pesos in total savings, 6,010 of which is they report holding at PALFSI. The corresponding administrative data on PALFSI savings in the control group has a mean $(5,619$ pesos $)$ very close to the survey-reported outcome, which provides confidence in the survey-reported data. Corresponding figures for loan balances are 11,262 in total, 7,842 at PALFSI, and 9,318 in the administrative data. For loan balances, it appears that there is slight underreporting of loan balances in the survey compared to the administrative data.

Neither treatment has large or statistically significant effects on savings, in either survey or administrative data. Point estimates are in fact slightly negative. These findings concord with the absence of treatment effects on meeting savings goals in Table 1 . 
By contrast, we find that the aspirations treatment leads individuals to have smaller outstanding loan balances. The aspirations treatment lowers survey-reported total loan balances by 1,734 pesos (a 15.4\% reduction from the control mean) and PALFSI loan balances by 1,202 pesos (both these coefficients are statistically significantly at the $5 \%$ level). The coefficient estimate for PALFSI loan balances calculated from administrative data is very similar, -1,257 pesos (statistically significant at the $10 \%$ level). These treatment effects in loans are also statistically significant after MHT adjustments.

The reduction in outstanding loan balance is accompanied by reduced business investments, as seen in Panel C. The aspirations treatment leads business investments in the last six months to be lower by 630 pesos (37\% below the control group). PALSFI's microloans are typically made with business uses in mind, so this finding concords with interpreting our negative treatment effects on loans as due to less desire on the part of individuals to invest in their businesses.

Similar patterns emerge when looking at the number of outstanding loans respondents have, in Appendix Table A3. In the control group, respondents have 1.35 loans in total, about 1.0 of which is at PALFSI. The aspirations treatment leads to 0.12 fewer total loans, and about 0.087 or 0.084 fewer PALFSI loans (in the survey and administrative data respectively). The treatment effect on total loans is significant at the $5 \%$ level.

A slight aside is in order, returning to the results on savings goals. Genicot \& Ray $(2017,2020)$ would also predict that people respond to failure by reducing their aspirations, so as to reduce the pain of frustration. While we do not have the data to explore how aspirations have changed over time, we speculate that savings goals could have been even higher immediately after the aspirations treatment, in which case the aspirations treatment effects on savings goals in Table 1 would be lower bounds of the immediate post-treatment impacts on savings goals.

\section{Mechanisms and channels of impact}

The aspirations treatment led participants to raise their savings goals, but most individuals failed to meet those goals. The aspirations treatment did not increase savings, and in fact led respondents to borrow less. These results are consistent with the possibility highlighted in Genicot \& Ray $(2017,2020)$. If people set aspirations too high, they may fail to reach their goals, and become frustrated or discouraged. As a result, they subsequently reduce their economic investments. In

light of this model, our finding that the aspirations treatment causes respondents to reduce their borrowing could be due to discouragement stemming from the failure to reach their goals.

That said, other explanations for these results are possible. We conducted the endline survey two years after treatment. One might speculate that perhaps savings did increase at some point after treatment, and respondents withdrew these savings at some point prior to the endline survey to invest in their businesses. We would thus see no increase in savings in the endline survey, and a reduction in borrowing because entrepreneurs were now able to finance their investments via 
savings instead of credit. In what follows, we conduct additional analyses to rule out this competing explanation, as well as to further understand the impact of the aspirations treatment.

\subsection{Dynamic impacts on savings and borrowing}

To address the alternative hypothesis that savings did increase (and then were withdrawn) prior to the endline survey, we examine administrative data on saving at PALFSI across different time periods after treatment. Appendix Table A4 shows that savings held in PALFSI accounts evolve similarly for clients in treatment and control groups. We divide the post-treatment period into five periods. The final period corresponds to the period in which we administered the endline survey.

In the first five months after all aspirations training was completed (September 2013 to January 2014), average savings in the aspirations group was only 39.5 pesos higher, compared to 5,992 in the control group (the differences are not statistically significant). Similarly, savings towards the end of the study period (May 2015 to August 2015), the last few months for which administrative data are available, are similar for the two treatment groups and control. It is thus not the case that treated individuals built up large savings that they then withdrew before the endline.

Appendix Table A4 also shows the corresponding administrative data on PALFSI loan balances over the same time period. This examines a related hypothesis that perhaps individuals receiving the aspirations treatment increased their borrowing immediately after treatment, achieved their investment goals, and subsequently decreased their borrowing by the time of the endline survey. The data are not consistent with this alternative explanation, with treated individuals having similar debt levels as the control group right after training, before borrowing declines for the treated towards our endline period.

Further, if treated respondents were able to finance their investments through increased savings between treatment and endline, we might observe positive impacts on business and non-business investments at endline. In Appendix Table A5, we show that the treatment did not lead individuals to start new businesses. There are no differences in total business value or household assets. In sum, there is no evidence for the alternative hypothesis that respondents in the aspirations treatment achieved their savings and investment goals in the time period before the endline survey.

\subsection{Impact on expenditures}

Mean monthly household income reported by households in our follow-up survey is 11,283 pesos (\$267), which is less than mean monthly household expenditures of 13,124 pesos (\$311). Even allowing for some underreporting of incomes, this suggests households are spending all they earn. Both training programs emphasized that a key way to increase savings was through reducing expenditure. The knowledge training highlighted the value of forgoing typical temptation goods like lottery tickets, cigarettes, and alcohol, while the aspirations training emphasized the value of delaying gratification in the short-term to build long-term opportunities. 
We examine in Appendix Table A6 whether individuals followed this advice by modifying their spending habits. We examine impacts on total household expenditure, as well as expenditure subcategories: food consumed outside the home, temptation goods, celebrations, durable goods, and education. Estimated effects of both the aspirations and knowledge treatments are small in magnitude, and none are statistically significantly different from zero.

Given that both aspirations and knowledge treatment encourage clients to reduce temptation spending, the absence of impacts on temptation spending is striking. This is despite clients saying they do spend on goods that they regret later. In the control group, $84 \%$ of clients said they regretted spending on alcohol, $84 \%$ on tobacco, and $63 \%$ on gambling and lotteries. That we find no effect of the aspirations treatment on temptation spending suggests that consumption habits are very "sticky" and hard to break (Berry et al., 2018; Bruhn et al., 2014).

This analysis helps explain why households are not saving more: they spend almost all they earn, and are unable to cut back on spending, despite saying they regret some of the spending that they do. Instead, they reduce borrowing and investments in their business. All told, these results are consistent with the Genicot \& Ray $(2017,2020)$ model, in which frustration stemming from not achieving goals leads individuals to scale back their economic investments.

\subsection{Impacts on locus of control and time preferences}

We now explore an additional reason why individuals may reduce their economic investments: their preference parameters or beliefs may change in such a way as to lead them to be less willing to invest. This mechanism is separate from, but complementary to, the mechanism in Genicot \& Ray $(2017,2020)$. Their model does not contemplate additional effects resulting from changes in individuals' preferences or beliefs. In our endline survey, we measured two such factors: locus of control and present bias. We consider these in turn.

Locus of control measures how strongly people believe they have control over situations and experiences that affect their lives (Rotter, 1954, 1966). Those who believe that events in their lives are primarily a result of their own actions have higher scores and are referred to as having "internal locus of control", whereas those who attribute life events to outside factors have "external locus of control." Locus of control plays a central role in our aspirations treatment, as well as other mindset-based approaches to financial education. The aspirations treatment emphasizes that personal obstacles can be overcome through a positive mindset, seeking to convince individuals that they are in control of their future through their savings decisions. In Secrets of the Millionaire Mind, Eker (2005) argues that rich people believe "I create my life" while poor people believe "life happens to me". This content is explicitly included in the culminating "rich mindset" session of the aspirations treatment.

In the endline survey, we use a seven-item set of questions that measure economic internal locus of control, derived from Furnham (1986). We ask individuals to say how much they agree or 
disagree on a Likert scale with statements like "Whether or not I get to become wealthy depends mostly on my ability" and "If I become poor, it's usually my own fault". ${ }^{13}$ We code each of the seven items so that higher scores indicate internal locus of control and sum the total. Table 3 shows that the aspirations treatment has a negative effect on internal locus of control that is statistically significant at the 5\% level. The knowledge treatment also has a negative effect, also significant at the $5 \%$ level. Both treatments significantly reduce the extent to which individuals believe their own actions determine their financial lives.

Why did training have the opposite effect on locus of control than intended? We have seen that training resulted in clients setting substantially higher savings goals than individuals in the control group, but that the average individual had only saved a tiny fraction (5\%) of this goal, and that treatment did not make individuals any more likely to achieve their goals. It is possible that encouraging people to have big dreams and set ambitious goals in a context where they are not able to meet these goals might have eventually demotivated or frustrated them and lead them to conclude that their actions do not determine their financial outcomes.

Taking the above evidence as a whole, we then speculate that the fall in loans and in business investment in the treated groups may be explained as follows: training caused participants to set ambitious savings goals, but they did not change their spending behavior, and as a result, they were far from meeting these savings goals. This led to frustration, and reductions in economic investments. These effects could have been compounded by individuals in the aspirations treatment coming to believe that their own actions would have little influence in determining their financial success (lower internal locus of control). Such a change in beliefs could have reinforced the discouragement effect, further lowering individuals' desire to invest in their businesses.

We also explore whether the treatments affect present bias. The aspirations treatment explicitly tries to get individuals to be less present-biased. The fourth aspirations session presented participants a video of the "marshmallow" experiment to highlighting the gains from making current sacrifices for future gains. ${ }^{14}$ The knowledge intervention gets individuals to think of their future selves through lifecycle planning and an emphasis on reducing temptation spending.

We measure present bias using by asking individuals to make hypothetical choices between different money amounts tomorrow versus in one month, and in two months versus three months, and seeing whether there are preference reversals. ${ }^{15}$ Table 3 shows that, on average, $13 \%$ of choices in the control group are present biased, and that neither the aspirations nor the knowledge treatment has a large or statistically significant effect on present bias. This lack of impact on time preferences is consistent with individuals not changing their temptation spending and suggests that while high

\footnotetext{
${ }^{13}$ The full set of questions is available in Appendix III.

${ }^{14}$ Gabaix and Laibson (2017) show theoretically that improving the accuracy of forecasting (say, by thinking carefully about intertemporal tradeoffs) can lead individuals to appear more patient. Alan and Ertac (2018) show that an educational intervention that gets children to better imagine their future selves was able to increase patience.

${ }^{15}$ Our procedures for measuring present bias are detailed in Appendix III.
} 
discount rates may help explain why individuals undersave, the treatments did not change this preference parameter.

\section{Conclusions}

Encouraging small-scale entrepreneurs to increase their financial aspirations did lead individuals to set higher savings goals, but most individuals failed to achieve their goals. Two years after the treatment, treated individuals had no higher savings, and - strikingly - were borrowing substantially less (in total and from the partner microfinance institution). The aspirations treatment also led to lower business investment. Genicot \& Ray $(2017,2020)$ emphasize that, in theory, setting higher aspirations may lead to higher economic investments, but failure to achieve aspirations may lead to frustration, and a decline in economic investments. Our results provide empirical support for this theory. Aspirations should therefore be set high, but not too high. The aspirations treatment we study may have set individuals' goals too high to be achievable, leading to discouragement and a decline in investments. We also find that the aspirations treatment reduced internal locus of control. This is an outcome of interest in itself, and it may also be an additional mechanism through which the ultimate negative impacts on investment arose.

This study suggests several avenues for future research. Perhaps most prominently: would an intervention that encouraged individuals to set more modest aspirations have had a more positive impact? Aspirations that were more modest would have been more achievable, reducing the negative consequences from frustration and discouragement. Future studies could investigate multiple treatment arms where individuals are encouraged to set different-sized financial goals, to explore whether lower, more manageable goals have more positive effects. 


\section{References}

Alan, S., \& Ertac, S. (2018). Fostering Patience in the Classroom: Results from a Randomized Educational Intervention. Journal of Political Economy, 126(5), 1865-1911.

Appadurai, A. (2004). The Capacity to Aspire: Culture and The Terms of Recognition. In V. Rao \& M. Walton (Eds.), Culture and Public Action (pp. 59-84). Stanford University Press.

Beaman, L., Duflo, E., Pande, R., \& Topalova, P. (2012). Female Leadership Raises Aspirations and Educational Attainment for Girls: A Policy Experiment in India. Science, 335(6068), 582-586.

Bernard, T., Dercon, S., Orkin, K., \& Taffesse, A. S. (2018). The Future in Mind: Short and Long-Run Impact of an Aspirations Intervention in Rural Ethiopia. Working Paper, University of Oxford.

Berry, J., Karlan, D., \& Pradhan, M. (2018). The Impact of Financial Education for Youth in Ghana. World Development, 102(C), 71-89.

Brown, A., \& Gartner, K. (2007). Early Intervention and Credit Cardholders. Retrieved March 15, 2013 from http://cfsinnovation.com/system/files/imported/managed documents/earlyintervention.pdf

Bruhn, M., Ibarra, G. L., \& McKenzie, D. (2014). The minimal impact of a large-scale financial education program in Mexico City. Journal of Development Economics, 108, 184-189.

Carlana, M., La Ferrara, E., \& Pinotti, P. (forthcoming). Goals and Gaps: Educational Careers of Immigrant Children. Econometrica.

Carpena, F., Cole, S., Shapiro, J., \& Zia, B. (2019). The ABCs of Financial Education: Experimental Evidence on Attitudes, Behavior and Cognitive Biases. Mangement Science, 65(1), 346-369.

Clark, D., Gill, D., Prowse, V., \& Rush, M. (2019). Using Goals to Motivate College Students: Theory and Evidence from Field Experiments. The Review of Economics and Statistics, 102(4), 648-663.

Cobb-Clark, D. A. (2014). Locus of Control and the Labor Market. IZA Discussion Paper No. 8678.

Cole, S., Sampson, T., \& Zia, B. (2011). Prices or Knowledge? What Drives Demand for Financial Services in Emerging Markets? Journal of Finance, 66(6), 1933-1967.

Dalton, P., Ghosal, S., \& Mani, A. (2016). Poverty and Aspirations Failure. The Economic Journal, 126(590), 165-188.

Duflo, E. (2012). Human values and the design of the fight against poverty. Tanner Lectures.

Eker, T. H. (2005). Secrets of the Millionaire Mind: Mastering the Inner Game of Wealth. Harper Business.

Fernandes, D., Lynch, J., \& Netemeyer, R. (2014). Financial Literacy, Financial Education and Downstream Financial Behaviors. Management Science, 60(8), 1861-2109.

Field, E., Jayachandran, S., \& Pande, R. (2010). Do Traditional Institutions Constrain Female Entrepreneurship? A Field Experiment on Business Training in India. American Economic Review: Papers and Proceedings, 100, 125-129.

Furnham, A. (1986). Economic Locus of Control. Human Relations, 39(1), 29-43.

Gabaix, X., \& Laibson, D. (2017). Myopia and Discounting. NBER Working Paper 23254.

Galiani, S., Gertler, P., \& Undurraga, R. (2018). Aspiration Adaptation in Resource-Constrained Environments. NBER Working Paper 24264.

Genicot, G., \& Ray, D. (2017). Aspirations and Inequality. Econometrica, 85(2), 489-519.

Genicot, G., \& Ray, D. (2020). Aspirations and Economic Behavior. Annual Review of Economics, 12, 715746.

Ghosal, S., Jana, S., Mani, A., Mitra, S., \& Roy, S. (2020). Sex workers, Stigma and Self-Image: Evidence from Kolkata Brothels. The Review of Economics and Statistics, Advance Publication.

Giné, X., \& Mansuri, G. (2020). Money or Management? A Field Experiment on Constraints to Entrepreneurship in Rural Pakistan. Economic Development and Cultural Change, forthcoming. 
Gottschalk, P. (2005). Can work alter welfare recipients' beliefs? Journal of Policy Analysis and Management, 24(3), 485-498.

Ibarra, G. L., McKenzie, D., \& Ortega, C. R. (2019). Estimated Treatment Effects with Big Data When Take-up is Low: An Application to Financial Education. The World Bank Economic Review, forthcoming.

Janzen, S. A., Magnan, N. P., Sharma, S., \& Thompson, W. M. (2017). Aspirations failure and formation in rural Nepal. Journal of Economic Behavior \& Organization, 139, 1-25.

Judge, T. A., Erez, A., Bono, J. E., \& Thoresen, C. J. (2002). Are measures of self-esteem, neuroticism, locus of control and generalized self-efficacy indicators of a common core construct? Journal of Personality and Social Psychology, 83, 693-710.

Karlan, D., \& Validivia, M. (2011). Teaching Entrepreneurship: Impact of Business Training on Microfinance Clients and Institutions. Review of Economics and Statistics, 93(2), 510-527.

Kiyosaki, R. T. (2017). Rich Dad Poor Dad: What the Rich Teach Thier Kids About Money That the Poor and Middle Class Do Not! Plata Publishing.

Knowles, J. (2018). A Meta-Analysis of the Take-Up and Utilization of Formal Savings Accounts.

Lusardi, A. (2001). Explaining Why So Many Households Do Not Save. Center for Retirement Research Working Paper.

Lybbert, T., \& Wydick, B. (2016). Hope as Aspirations, Agency and Pathways: Poverty Dynamics and Microfinance in Oaxaca, Mexico. NBER Working Paper 22661.

Lybbert, T., \& Wydick, B. (2018). Poverty, Aspirations and the Economics of Hope. Economic Development and Cultural Change, 66(4).

Macours, K., \& Vakis, R. (2014). Changing households' investment behaviour through social interactions with local leaders: Evidence from a randomised transfer programme. The Economic Journal, 124(576), 607-633.

McKelway, M. (2021). Women's Agency and Women's Employment: How Women's Sense of Agency Affects Their Labor Supply. Working Paper.

Mischel, W., \& Ebbesen, E. B. (1970). Attention in delay of gratification. Journal of Personality and Social Psychology, 16(2), 329-337.

Mukherjee, P. (2017). The Effects of Social Identity on Aspirations and Learning Outcomes. International Growth Centre Working Paper S-35120-INC-7.

Muralidharan, K., Romero, M., \& Wuthrich, K. (2021). Factorial designs, model selection, and (incorrect) inference in randomized experiments. NBER Working Paper 26562.

$\mathrm{Ng}$, T. W. H., Sorensen, K. L., \& Eby, L. T. (2006). Locus of control at work: a meta-analysis. Journal of Organizational Behavior, 27(8), 1057-1087.

Pederson, P., Sogaard, H. J., Labriola, M., Nohr, E. A., \& Jensen, C. (2015). Effectiveness of psychoeducation in reducing sickness absence and improving mental health in individuals at risk of having a mental disorder: a randomised controlled trial. BMC Public Health, 15(1), 763.

Riley, E. (2020). Role Models in Movies: The Impact of Queen of Katwe on Students' Educational Outcomes. Working Paper.

Ross, P. H. (2019). Occupation aspirations, education investment, and cognitive outcomes: Evidence from Indian adolescents. World Development, 123.

Rotter, J. B. (1954). Social Learning and Clinical Psychology. Prentice-Hall.

Rotter, J. B. (1966). Generalized expectancies for internal versus external control of reinforcement. Psychological Monographs: General and Applied, 80, 1-28.

Salamanca, N., de Grip, A., Fouarge, D., \& Montizaan, R. (2020). Locus of Control and Investment in Risky Assets. Journal of Economic Behavior \& Organization, 177(548-568).

Seshan, G., \& Yang, D. (2014). Motivating migrants: A field experiment on financial decision-making in transnational households. Journal of Development Economics, 108, 119-127. 
Shoji, M. (2020). Early-Life Circumstances and Adult Locus of Control: Evidence from 46 Developing Countries. Working Paper.

World Bank. (2020). World Development Indicators https://datatopics.worldbank.org/worlddevelopment-indicators/ 


\section{Figures and Tables}

Figure 1: Distribution of savings goals met, by treatment
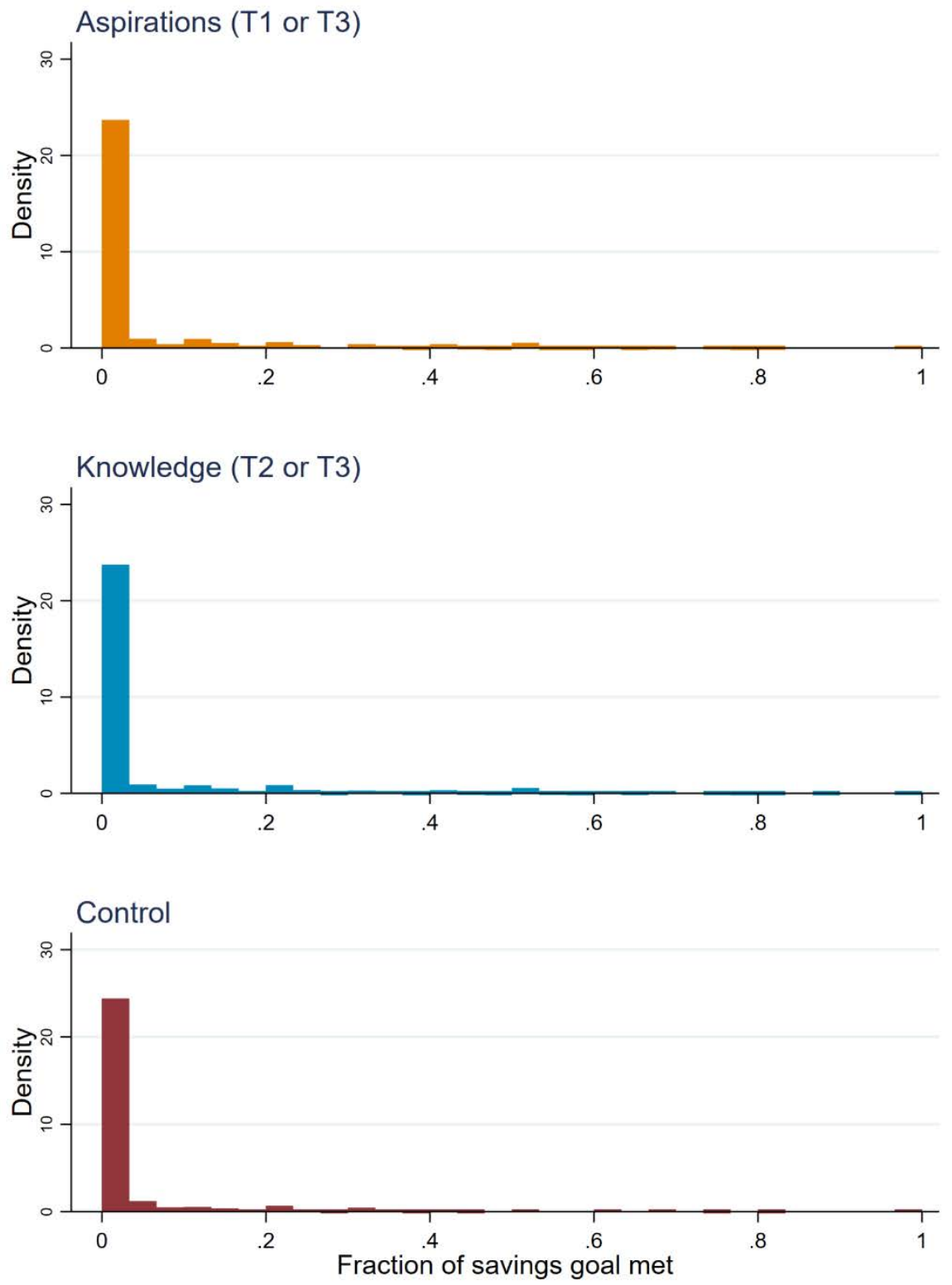

Notes: The figure plots histograms of fraction of savings goal met (savings divided by savings goal), among individuals with nonzero savings goals, by treatment group. Data are from endline survey. 
Table 1: Impact on retention of training concepts and savings goals

\begin{tabular}{|c|c|c|c|c|c|}
\hline & (1) & (2) & (3) & (4) & (5) \\
\hline & $\begin{array}{l}\text { Number of } \\
\text { observations }\end{array}$ & $\begin{array}{c}\text { Mean of } \\
\text { control }\end{array}$ & Aspirations & Knowledge & $\begin{array}{c}\text { Aspirations } \\
= \\
\text { Knowledge } \\
\text { (p-value) }\end{array}$ \\
\hline \multicolumn{6}{|l|}{ Panel A: Training concepts retention } \\
\hline Aspirations related questions ( 3 questions) & 2,464 & 22.2 & $\begin{array}{l}1.99 * * \\
(0.880) \\
{[0.077]}\end{array}$ & $\begin{array}{l}-0.012 \\
(0.873) \\
{[1.000]}\end{array}$ & 0.102 \\
\hline Knowledge related questions (5 questions) & 2,464 & 39.7 & $\begin{array}{l}-0.756 \\
(1.034) \\
{[0.363]} \\
\end{array}$ & $\begin{array}{c}3.08^{* * *} \\
(1.056) \\
{[0.022]} \\
\end{array}$ & 0.011 \\
\hline \multicolumn{6}{|l|}{ Panel B: Savings goals } \\
\hline Total savings goals (pesos) & 2,464 & 29,643 & $\begin{array}{c}5,372 \\
(4,224) \\
{[0.196]}\end{array}$ & $\begin{array}{c}-266 \\
(4,130) \\
{[1.000]}\end{array}$ & 0.350 \\
\hline Savings goal as share of annual income & 2,454 & 0.240 & $\begin{array}{l}0.097 * \\
(0.056) \\
{[0.090]}\end{array}$ & $\begin{array}{l}-0.017 \\
(0.058) \\
{[1.000]}\end{array}$ & 0.258 \\
\hline Education savings goals (pesos) & 2,464 & 14,753 & $\begin{array}{l}7,116^{* *} \\
(2,932) \\
{[0.072]} \\
\end{array}$ & $\begin{array}{l}-1,202 \\
(3,126) \\
{[1.000]} \\
\end{array}$ & 0.055 \\
\hline \multicolumn{6}{|l|}{ Panel C: Meeting savings goals } \\
\hline Fraction of savings goal met & 2,464 & 0.050 & $\begin{array}{c}0.006 \\
(0.006) \\
{[0.352]}\end{array}$ & $\begin{array}{l}-0.002 \\
(0.006) \\
{[1.000]}\end{array}$ & 0.332 \\
\hline Fraction of education savings goal met & 2,464 & 0.017 & $\begin{array}{c}0.003 \\
(0.004) \\
{[0.363]}\end{array}$ & $\begin{array}{c}0.002 \\
(0.004) \\
{[1.000]}\end{array}$ & 0.877 \\
\hline
\end{tabular}

Notes: Each row (dependent variable) reports results from a separate regression. Columns (3) and (4) report regressions coefficients from estimation Equation (1), where the treatments are pooled together into two categories (Aspirations $=\mathrm{T} 1$ or T3, and Knowledge $=\mathrm{T} 2$ or T3). All regressions include a constant and dummies for the sampling strata. Robust standard errors clustered at the center level are reported in parenthesis. To control for multiple hypothesis testing, sharpened q-values following Anderson (2008) are reported in square brackets. $* * *$ Significant at $1 \%, * *$ Significant at $5 \%, *$ Significant at $10 \%$. 
Table 2: Impact on financial outcomes

\begin{tabular}{|c|c|c|c|c|c|}
\hline & (1) & (2) & (3) & (4) & (5) \\
\hline & $\begin{array}{l}\text { Number of } \\
\text { observations }\end{array}$ & $\begin{array}{c}\text { Mean of } \\
\text { control }\end{array}$ & Aspirations & Knowledge & $\begin{array}{c}\text { Aspirations } \\
\quad= \\
\text { Knowledge } \\
\text { (p-value) }\end{array}$ \\
\hline \multicolumn{6}{|l|}{ Panel A: Savings } \\
\hline Total savings (pesos, survey) & 2,464 & 7,424 & $\begin{array}{c}-356 \\
(575) \\
{[0.203]}\end{array}$ & $\begin{array}{c}-315 \\
(567) \\
{[1.000]}\end{array}$ & 0.961 \\
\hline PALFSI savings (pesos, survey) & 2,420 & 6,010 & $\begin{array}{c}-432 \\
(497) \\
{[0.095]}\end{array}$ & $\begin{array}{c}-273 \\
(493) \\
{[1.000]}\end{array}$ & 0.825 \\
\hline PALFSI savings (pesos, admin) & 2,464 & 5,619 & $\begin{array}{c}-465 \\
(477) \\
{[0.095]} \\
\end{array}$ & $\begin{array}{c}-319 \\
(480) \\
{[1.000]}\end{array}$ & 0.839 \\
\hline \multicolumn{6}{|l|}{ Panel B: Loan accounts } \\
\hline Total loans (pesos, survey) & 2,464 & 11,262 & $\begin{array}{c}-1,734 * * \\
(745) \\
{[0.025]}\end{array}$ & $\begin{array}{c}-338 \\
(696) \\
{[1.000]}\end{array}$ & 0.109 \\
\hline PALFSI loans (pesos, survey) & 2,424 & 7,842 & $\begin{array}{c}-1,202 * * \\
(566) \\
{[0.025]}\end{array}$ & $\begin{array}{c}-328 \\
(543) \\
{[1.000]}\end{array}$ & 0.267 \\
\hline PALSFI loans (pesos, admin) & 2,464 & 9,318 & $\begin{array}{c}-1,257^{*} \\
(760) \\
{[0.045]} \\
\end{array}$ & $\begin{array}{c}-272 \\
(767) \\
{[1.000]} \\
\end{array}$ & 0.331 \\
\hline \multicolumn{6}{|l|}{ Panel C: Business investments } \\
\hline Business investment (pesos, six monthly) & 2,463 & 1,692 & $\begin{array}{c}-630 * * \\
(293) \\
{[0.030]} \\
\end{array}$ & $\begin{array}{l}-91.6 \\
(276) \\
{[1.000]} \\
\end{array}$ & 0.140 \\
\hline
\end{tabular}

Notes: Each row (dependent variable) reports results from a separate regression. Columns (3) and (4) report regressions coefficients from estimation Equation (1), where the treatments are pooled together into two categories (Aspirations $=\mathrm{T} 1$ or T3, and Knowledge $=\mathrm{T} 2$ or T3). All regressions include a constant and dummies for the sampling strata. Robust standard errors clustered at the center level are reported in parenthesis. To control for multiple hypothesis testing, sharpened q-values following Anderson (2008) are reported in square brackets. $* * *$ Significant at $1 \%,{ }^{* *}$ Significant at $5 \%, *$ Significant at $10 \%$. 
Table 3: Impact on training on locus of control and time preferences

\begin{tabular}{|c|c|c|c|c|c|}
\hline & (1) & (2) & (3) & (4) & $(5)$ \\
\hline & $\begin{array}{l}\text { Number of } \\
\text { observations }\end{array}$ & $\begin{array}{c}\text { Mean of } \\
\text { control }\end{array}$ & Aspirations & Knowledge & $\begin{array}{c}\text { Aspirations } \\
\quad= \\
\text { Knowledge } \\
\text { (p-value) }\end{array}$ \\
\hline Internal locus of control & 2,463 & 41.8 & $\begin{array}{c}-0.776^{* *} \\
(0.325) \\
{[0.010]}\end{array}$ & $\begin{array}{c}-0.584 * * \\
(0.295) \\
{[0.074]}\end{array}$ & 0.682 \\
\hline $\begin{array}{l}\text { Present bias (fraction of } \\
\text { choices) }\end{array}$ & 2,464 & 0.134 & $\begin{array}{l}0.010 \\
(0.012) \\
{[0.258]}\end{array}$ & $\begin{array}{l}-0.015 \\
(0.011) \\
{[0.116]}\end{array}$ & 0.180 \\
\hline
\end{tabular}

Notes: Each row (dependent variable) reports results from a separate regression. Columns (3) and (4) report regressions coefficients from estimation Equation (1), where the treatments are pooled together into two categories (Aspirations = T1 or T3, and Knowledge $=\mathrm{T} 2$ or T3). All regressions include a constant and dummies for the sampling strata. Robust standard errors clustered at the center level are reported in parenthesis. *** Significant at $1 \%$, ** Significant at 5\%, * Significant at $10 \%$. 


\section{Appendix I: Additional Results}

Figure A1: Randomization and treatment assignment

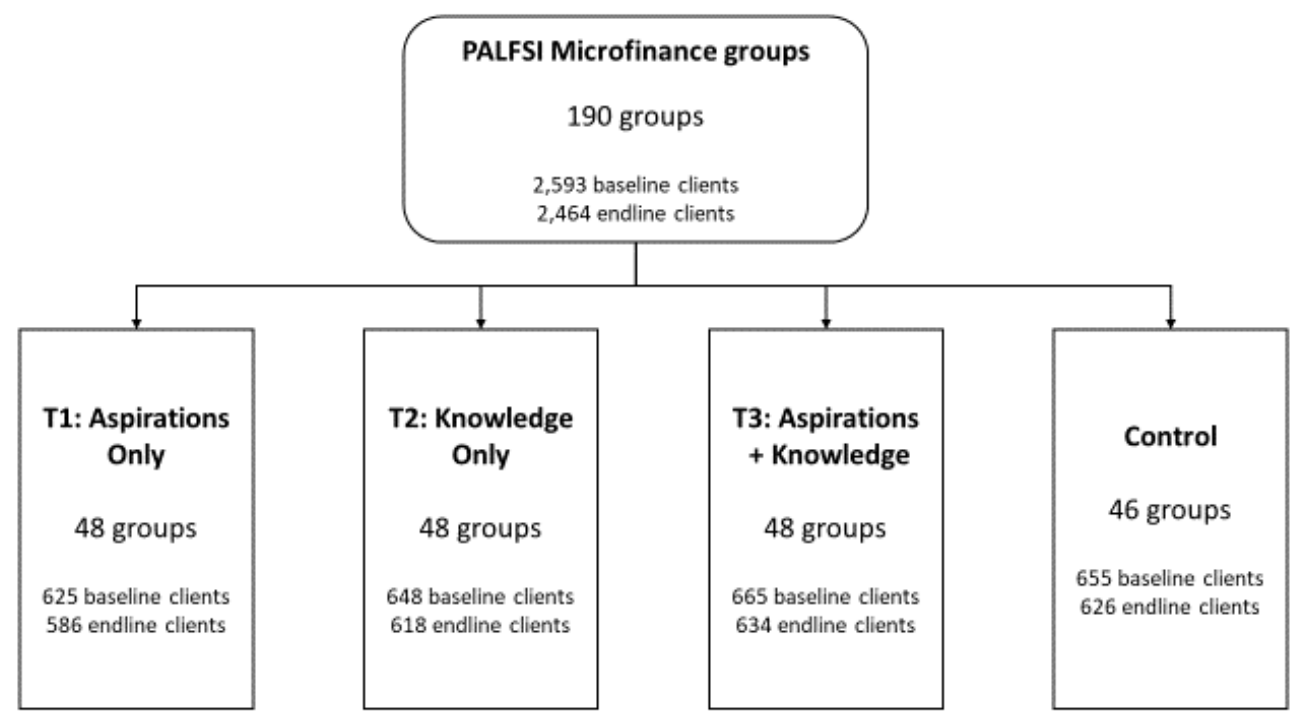

Figure A2: Timeline of the evaluation

Aspirations only

(T1)

Knowledge only

(T2)

Both aspirations and knowledge

(T3)

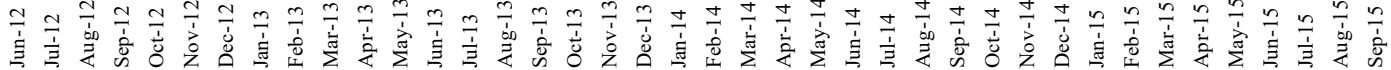

Control

\begin{tabular}{lcccc}
\hline Surveys & \multicolumn{2}{c}{ Baseline survey } & Endline Survey \\
Administrative data & Pre-period & During period & Post-period & \\
\hline
\end{tabular}


Figure A3. Attendance in trainings by treatment

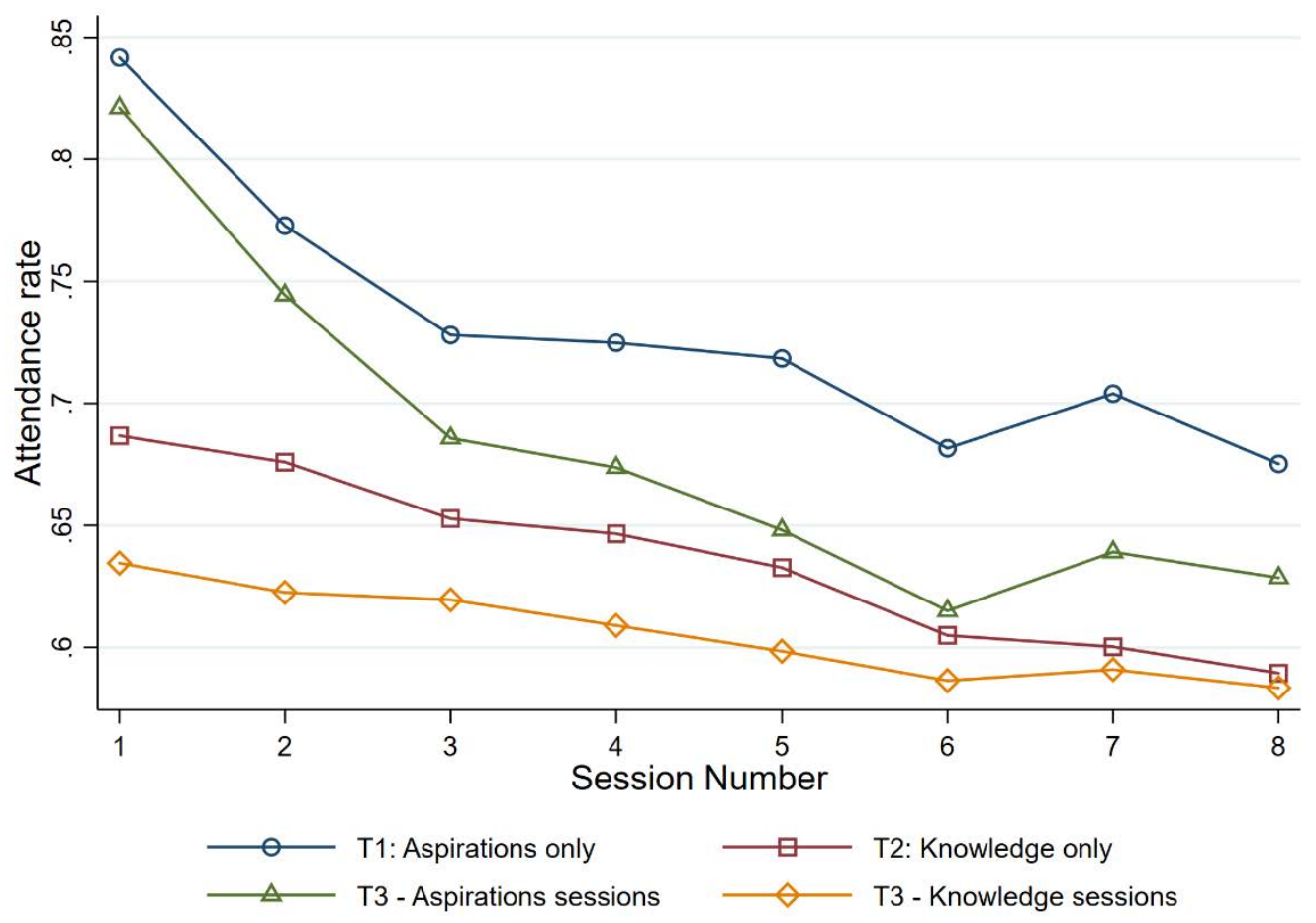


Table A1. Sample description and balance

\begin{tabular}{|c|c|c|c|c|c|c|c|c|c|c|c|}
\hline & $\begin{array}{c}\text { (1) } \\
\text { Number of } \\
\text { observations }\end{array}$ & $\begin{array}{c}\text { (2) } \\
\text { Mean of } \\
\text { control }\end{array}$ & Aspirations & $\begin{array}{c}\text { (4) } \\
\text { Knowledge }\end{array}$ & $\begin{array}{c}(5) \\
\text { Aspirations } \\
= \\
\text { Knowledge } \\
\text { (p-value) }\end{array}$ & $\begin{array}{c}\text { (6) } \\
\text { Aspirations } \\
\text { only } \\
\text { (T1) }\end{array}$ & $\begin{array}{c}(7) \\
\text { Knowledge } \\
\text { only } \\
\text { (T2) }\end{array}$ & $\begin{array}{c}(8) \\
\text { Aspirations } \\
+ \\
\text { Knowledge } \\
\text { (T3) }\end{array}$ & $\begin{array}{c}(9) \\
\mathrm{T} 1=\mathrm{T} 2= \\
\mathrm{T} 3 \\
\text { (p-value) }\end{array}$ & $\begin{array}{c}(10) \\
\mathrm{T} 1=\mathrm{T} 3 \\
\text { (p-value) }\end{array}$ & $\begin{array}{c}(11) \\
\mathrm{T} 2=\mathrm{T} 3 \\
\text { (p-value) }\end{array}$ \\
\hline \multicolumn{12}{|l|}{ Panel A: Sample description } \\
\hline Endline completed (1=yes) & 2,593 & 0.956 & $\begin{array}{l}-0.007 \\
(0.010)\end{array}$ & $\begin{array}{c}0.007 \\
(0.010) \\
\end{array}$ & 0.287 & $\begin{array}{l}-0.018 \\
(0.014) \\
\end{array}$ & $\begin{array}{l}-0.003 \\
(0.014) \\
\end{array}$ & $\begin{array}{l}-0.000 \\
(0.014) \\
\end{array}$ & 0.402 & 0.229 & 0.869 \\
\hline \multicolumn{12}{|c|}{ Panel B: Demographic characteristics and savings at baseline } \\
\hline Client is female (1=yes) & 2,459 & 0.923 & $\begin{array}{l}-0.005 \\
(0.012)\end{array}$ & $\begin{array}{l}0.026^{* *} \\
(0.011)\end{array}$ & 0.078 & $\begin{array}{l}-0.015 \\
(0.017)\end{array}$ & $\begin{array}{c}0.016 \\
(0.017)\end{array}$ & $\begin{array}{c}0.022 \\
(0.015)\end{array}$ & 0.060 & 0.023 & 0.733 \\
\hline Age of client (years) & 2,460 & 47.1 & $\begin{array}{l}-0.270 \\
(0.565)\end{array}$ & $\begin{array}{l}-0.648 \\
(0.571)\end{array}$ & 0.671 & $\begin{array}{l}-0.411 \\
(0.752)\end{array}$ & $\begin{array}{l}-0.785 \\
(0.834)\end{array}$ & $\begin{array}{l}-0.921 \\
(0.708)\end{array}$ & 0.794 & 0.501 & 0.870 \\
\hline Client is married (1=yes) & 2,464 & 0.805 & $\begin{array}{l}-0.017 \\
(0.016)\end{array}$ & $\begin{array}{c}0.006 \\
(0.016)\end{array}$ & 0.312 & $\begin{array}{c}0.020 \\
(0.022)\end{array}$ & $\begin{array}{l}0.042 * * \\
(0.021)\end{array}$ & $\begin{array}{l}-0.010 \\
(0.022)\end{array}$ & 0.051 & 0.175 & 0.015 \\
\hline Client is high school or more educated & 2,464 & 0.562 & $\begin{array}{c}0.017 \\
(0.029)\end{array}$ & $\begin{array}{l}-0.026 \\
(0.027)\end{array}$ & 0.280 & $\begin{array}{c}0.033 \\
(0.038)\end{array}$ & $\begin{array}{l}-0.011 \\
(0.039)\end{array}$ & $\begin{array}{l}-0.009 \\
(0.039)\end{array}$ & 0.432 & 0.283 & 0.966 \\
\hline Total savings (in pesos) & 2,464 & 8,320 & $\begin{array}{c}788 \\
(705)\end{array}$ & $\begin{array}{c}347 \\
(735)\end{array}$ & 0.657 & $\begin{array}{c}909 \\
(1,005)\end{array}$ & $\begin{array}{c}464 \\
(1,001)\end{array}$ & $\begin{array}{c}1,138 \\
(1,043)\end{array}$ & 0.787 & 0.828 & 0.502 \\
\hline Savings in PALFSI accounts (pesos) & 2,464 & 4,905 & $\begin{array}{c}37 \\
(344)\end{array}$ & $\begin{array}{c}59 \\
(342)\end{array}$ & 0.968 & $\begin{array}{c}416 \\
(477)\end{array}$ & $\begin{array}{c}425 \\
(456)\end{array}$ & $\begin{array}{c}104 \\
(424)\end{array}$ & 0.728 & 0.521 & 0.496 \\
\hline $\begin{array}{l}\text { Savings deposit frequency is at least weekly } \\
(1=\text { yes })\end{array}$ & 2,464 & 0.387 & $\begin{array}{c}0.038 \\
(0.045) \\
\end{array}$ & $\begin{array}{c}-0.027 \\
(0.046) \\
\end{array}$ & 0.338 & $\begin{array}{c}0.092 \\
(0.065) \\
\end{array}$ & $\begin{array}{c}0.024 \\
(0.064) \\
\end{array}$ & $\begin{array}{c}0.012 \\
(0.061) \\
\end{array}$ & 0.444 & 0.220 & 0.840 \\
\hline \multicolumn{12}{|c|}{ Panel C: Administrative data at baseline (July 2012 to October 2012) } \\
\hline Total savings (pesos) & 2,464 & 5,589 & $\begin{array}{c}-39 \\
(350)\end{array}$ & $\begin{array}{l}-274 \\
(347)\end{array}$ & 0.679 & $\begin{array}{l}-180 \\
(460)\end{array}$ & $\begin{array}{l}-410 \\
(475)\end{array}$ & $\begin{array}{l}-316 \\
(409)\end{array}$ & 0.919 & 0.782 & 0.852 \\
\hline Outstanding loan balance (pesos) & 2,464 & 8,693 & $\begin{array}{c}73 \\
(400)\end{array}$ & $\begin{array}{c}81 \\
(388)\end{array}$ & 0.988 & $\begin{array}{l}-291 \\
(525)\end{array}$ & $\begin{array}{l}-271 \\
(535)\end{array}$ & $\begin{array}{c}147 \\
(540)\end{array}$ & 0.688 & 0.436 & 0.476 \\
\hline Net savings (pesos) & 2,464 & $-3,158$ & $\begin{array}{l}-125 \\
(269)\end{array}$ & $\begin{array}{c}-337 \\
(268)\end{array}$ & 0.560 & $\begin{array}{c}121 \\
(372)\end{array}$ & $\begin{array}{c}-99 \\
(403)\end{array}$ & $\begin{array}{l}-457 \\
(393)\end{array}$ & 0.237 & 0.091 & 0.343 \\
\hline
\end{tabular}

(Aspirations $=\mathrm{T} 1$ or T3, and Knowledge $=\mathrm{T} 2$ or T3). The second regression is in Columns (6)-(9), with three treatments (T1, T2 and T3) as separate independent variables. All regressions include a constant and dummies for the sampling strata. Robust standard errors clustered at the center level are reported in parenthesis. ${ }^{* *}$ Significant at $1 \%,{ }^{* *}$ Significant at $5 \%,{ }^{*}$ Significant at $10 \%$. 


\section{A note on short-form versus long-form results}

We cross-randomized the aspirations and knowledge treatments in a $2 \times 2$ design. At the time we designed this study, the rationale for doing this was to allow for the possibility that the two treatments would interact. However, we were unaware of just how much larger the sample size needs to be to detect interaction effects. Gelman (2018) offers as a rule of thumb that you need 16 times the sample size to detect an interaction effect as a main effect, while Blair et al. (2019) ${ }^{16}$ and Muralidharan, et al. (2021) also discuss the lower power of interaction designs. Power for estimating impacts in this "long-form" or saturated model that estimates separate treatment effects for each treatment and for their interaction is further reduced once one accounts for multiple hypothesis testing. For these reasons our preferred specification is the "short form" equation given in equation 1. We also present the "long-form" specifications in Tables A2, A3. A5 and A6 for comparison purposes.

${ }^{16}$ Blair, Graeme, Jasper Cooper, Alexander Coppock and Macartan Humphreys (2019) "Declaring and Diagnosing Research Designs", American Political Science Review 113(3): 838-59. 
Table A2: Impact on retention of training concepts and savings goals, long-form

\begin{tabular}{|c|c|c|c|c|c|c|c|c|}
\hline & $\begin{array}{c}\text { (1) } \\
\text { Number of } \\
\text { observations }\end{array}$ & $\begin{array}{c}\text { (2) } \\
\text { Mean of } \\
\text { control }\end{array}$ & $\begin{array}{c}\text { (3) } \\
\text { Aspirations } \\
\text { only } \\
\text { (T1) }\end{array}$ & $\begin{array}{c}(4) \\
\text { Knowledge } \\
\text { only } \\
\text { (T2) }\end{array}$ & $\begin{array}{c}(5) \\
\text { Aspirations } \\
+ \\
\text { Knowledge } \\
\text { (T3) } \\
\end{array}$ & $\begin{array}{c}(6) \\
\mathrm{T} 1=\mathrm{T} 2= \\
\mathrm{T} 3 \\
\text { (p-value) }\end{array}$ & $\begin{array}{c}(7) \\
\mathrm{T} 1=\mathrm{T} 3 \\
\text { (p-value) }\end{array}$ & $\begin{array}{c}(8) \\
\mathrm{T} 2=\mathrm{T} 3 \\
\text { (p-value) }\end{array}$ \\
\hline \multicolumn{9}{|l|}{ Panel A: Training concepts retention } \\
\hline Aspirations related questions (3 questions) & 2,464 & 22.151 & $\begin{array}{c}3.738^{* * *} \\
(1.192)\end{array}$ & $\begin{array}{c}1.677 \\
(1.152)\end{array}$ & $\begin{array}{c}2.019 \\
(1.235)\end{array}$ & 0.189 & 0.161 & 0.775 \\
\hline Knowledge related questions ( 5 questions) & 2,464 & 39.736 & $\begin{array}{l}-1.781 \\
(1.535)\end{array}$ & $\begin{array}{c}2.084 \\
(1.484) \\
\end{array}$ & $\begin{array}{r}2.299 \\
(1.461) \\
\end{array}$ & 0.011 & 0.006 & 0.876 \\
\hline \multicolumn{9}{|l|}{ Panel B: Savings goals } \\
\hline Total savings goals (pesos) & 2,464 & 29,643 & $\begin{array}{c}11,533^{* *} \\
(5,845)\end{array}$ & $\begin{array}{c}5,697 \\
(5,800)\end{array}$ & $\begin{array}{c}5,241 \\
(5,769)\end{array}$ & 0.488 & 0.273 & 0.937 \\
\hline Savings goal as share of annual income & 2,454 & 0.240 & $\begin{array}{c}0.197 * * \\
(0.099)\end{array}$ & $\begin{array}{l}0.080^{*} \\
(0.046)\end{array}$ & $\begin{array}{c}0.083 \\
(0.052)\end{array}$ & 0.502 & 0.276 & 0.959 \\
\hline Education savings goals (pesos) & 2,464 & 14,753 & $\begin{array}{l}8,905^{* *} \\
(4,372) \\
\end{array}$ & $\begin{array}{c}530 \\
(3,308) \\
\end{array}$ & $\begin{array}{c}5,952 \\
(4,260) \\
\end{array}$ & 0.096 & 0.551 & 0.147 \\
\hline \multicolumn{9}{|l|}{ Panel C: Meeting savings goals } \\
\hline Fraction of savings goal met & 2,464 & 0.050 & $\begin{array}{c}0.008 \\
(0.010)\end{array}$ & $\begin{array}{l}-0.001 \\
(0.007)\end{array}$ & $\begin{array}{c}0.004 \\
(0.008)\end{array}$ & 0.591 & 0.674 & 0.525 \\
\hline Fraction of education savings goal met & 2,464 & 0.017 & $\begin{array}{c}0.008 \\
(0.006)\end{array}$ & $\begin{array}{c}0.007 \\
(0.005)\end{array}$ & $\begin{array}{c}0.006 \\
(0.005)\end{array}$ & 0.884 & 0.650 & 0.741 \\
\hline
\end{tabular}

dummies for the sampling strata. Robust standard errors clustered at the center level are reported in parenthesis. *** Significant at $1 \%$, ** Significant at $5 \%$, $*$ Significant at $10 \%$. 
Table A3: Impact on financial outcomes, long-form

\begin{tabular}{|c|c|c|c|c|c|c|c|c|}
\hline & $\begin{array}{c}\text { (1) } \\
\text { Number of } \\
\text { observations }\end{array}$ & $\begin{array}{c}\text { Mean of } \\
\text { control }\end{array}$ & $\begin{array}{c}\text { (3) } \\
\text { Aspirations } \\
\text { only } \\
\text { (T1) }\end{array}$ & $\begin{array}{c}\text { (4) } \\
\text { Knowledge } \\
\text { only } \\
\text { (T2) }\end{array}$ & $\begin{array}{c}(5) \\
\text { Aspirations } \\
+ \\
\text { Knowledge } \\
\text { (T3) }\end{array}$ & $\begin{array}{c}(6) \\
\mathrm{T} 1=\mathrm{T} 2= \\
\mathrm{T} 3 \\
\text { (p-value) }\end{array}$ & $\begin{array}{c}(7) \\
\mathrm{T} 1=\mathrm{T} 3 \\
\text { (p-value) }\end{array}$ & $\begin{array}{c}(8) \\
\mathrm{T} 2=\mathrm{T} 3 \\
\text { (p-value) }\end{array}$ \\
\hline \multicolumn{9}{|l|}{ Panel A: Savings } \\
\hline Total savings (pesos, survey) & 2,464 & 7,424 & $\begin{array}{c}183 \\
(784)\end{array}$ & $\begin{array}{c}207 \\
(738)\end{array}$ & $\begin{array}{l}-660 \\
(754)\end{array}$ & 0.477 & 0.314 & 0.283 \\
\hline PALFSI savings (pesos, survey) & 2,420 & 6,010 & $\begin{array}{c}222 \\
(654)\end{array}$ & $\begin{array}{c}358 \\
(672)\end{array}$ & $\begin{array}{l}-690 \\
(663)\end{array}$ & 0.249 & 0.177 & 0.136 \\
\hline PALFSI savings (pesos, admin) & 2,464 & 5,619 & $\begin{array}{r}369 \\
(637) \\
\end{array}$ & $\begin{array}{r}488 \\
(661) \\
\end{array}$ & $\begin{array}{r}-766 \\
(615) \\
\end{array}$ & 0.089 & 0.074 & 0.058 \\
\hline \multicolumn{9}{|l|}{ Panel B: Loan accounts } \\
\hline PALFSI loans (pesos, survey) & 2,424 & 7,842 & $\begin{array}{l}-461 \\
(780)\end{array}$ & $\begin{array}{c}384 \\
(732)\end{array}$ & $\begin{array}{c}-1,514^{* *} \\
(771)\end{array}$ & 0.050 & 0.179 & 0.015 \\
\hline PALSFI loans (pesos, admin) & 2,464 & 9,318 & $\begin{array}{l}-1,444 \\
(942)\end{array}$ & $\begin{array}{c}-453 \\
(1,160)\end{array}$ & $\begin{array}{l}-1,532 \\
(1,145)\end{array}$ & 0.566 & 0.927 & 0.354 \\
\hline Number of PALSFI loans (survey) & 2,464 & 1.347 & $\begin{array}{l}-0.070 \\
(0.084)\end{array}$ & $\begin{array}{l}-0.061 \\
(0.078)\end{array}$ & $\begin{array}{c}-0.230^{* * * *} \\
(0.077)\end{array}$ & 0.023 & 0.028 & 0.015 \\
\hline Number of PALSFI loans (admin) & 2,464 & 1.049 & $\begin{array}{l}-0.009 \\
(0.072) \\
\end{array}$ & $\begin{array}{l}-0.023 \\
(0.069) \\
\end{array}$ & $\begin{array}{c}-0.178^{* *} \\
(0.072) \\
\end{array}$ & 0.030 & 0.018 & 0.026 \\
\hline \multicolumn{9}{|l|}{ Panel C: Business investments } \\
\hline Business investment (pesos, six monthly) & 2,463 & 1,692 & $\begin{array}{l}-703^{*} \\
(389)\end{array}$ & $\begin{array}{l}-162 \\
(430)\end{array}$ & $\begin{array}{l}-723 * \\
(439)\end{array}$ & 0.283 & 0.955 & 0.184 \\
\hline
\end{tabular}

Notes: Each row (dependent variable) reports results from the regression of individual binary indicators for the three treatments (T1, T2 or T3). All regressions include a constant and dummies for the sampling strata. Robust standard errors clustered at the center level are reported in parenthesis. $* * *$ Significant at $1 \%$, ** Significant at $5 \%$, $*$ Significant at $10 \%$. 
Table A4: Dynamic impacts on savings and loans

\begin{tabular}{|c|c|c|c|c|c|c|c|}
\hline & (1) & (2) & (3) & (4) & (6) & (7) & (8) \\
\hline & \multicolumn{4}{|c|}{ Savings } & \multicolumn{3}{|c|}{ Loans } \\
\hline & $\begin{array}{c}\text { Number of } \\
\text { observations }\end{array}$ & $\begin{array}{c}\text { Mean of } \\
\text { control }\end{array}$ & Aspirations & Knowledge & $\begin{array}{c}\text { Mean of } \\
\text { control }\end{array}$ & Aspirations & Knowledge \\
\hline September 2013 - January 2014 & 2,464 & 5,992 & $\begin{array}{l}39.5 \\
(423)\end{array}$ & $\begin{array}{l}-687 \\
(419)\end{array}$ & 8,177 & $\begin{array}{c}883 \\
(693)\end{array}$ & $\begin{array}{l}-258 \\
(664)\end{array}$ \\
\hline February 2014 - June 2014 & 2,464 & 5,712 & $\begin{array}{l}-320 \\
(424)\end{array}$ & $\begin{array}{l}-425 \\
(421)\end{array}$ & 7,947 & $\begin{array}{l}-308 \\
(446)\end{array}$ & $\begin{array}{l}-584 \\
(412)\end{array}$ \\
\hline July 2014 - November 2014 & 2,464 & 5,466 & $\begin{array}{l}-341 \\
(451)\end{array}$ & $\begin{array}{l}-240 \\
(457)\end{array}$ & 7,584 & $\begin{array}{l}-372 \\
(470)\end{array}$ & $\begin{array}{l}-317 \\
(458)\end{array}$ \\
\hline December 2014 - April 2015 & 2,464 & 5,504 & $\begin{array}{l}-387 \\
(292)\end{array}$ & $\begin{array}{l}-162 \\
(292)\end{array}$ & 7,776 & $\begin{array}{l}-496 \\
(322)\end{array}$ & $\begin{array}{l}-359 \\
(322)\end{array}$ \\
\hline May 2015 - August 2015 & 2,464 & 5,619 & $\begin{array}{l}-471 \\
(306)\end{array}$ & $\begin{array}{l}-345 \\
(306)\end{array}$ & 9,318 & $\begin{array}{c}-1,404 \\
(877)\end{array}$ & $\begin{array}{l}-242 \\
(883)\end{array}$ \\
\hline All coefficients equal (Chi-stat/p-value) & & & $\begin{array}{c}4.70 \\
{[0.319]}\end{array}$ & $\begin{array}{c}7.22 \\
{[0.125]}\end{array}$ & & $\begin{array}{c}5.51 \\
{[0.239]}\end{array}$ & $\begin{array}{c}1.95 \\
{[0.745]}\end{array}$ \\
\hline
\end{tabular}


Table A5: Impact on business investments and assets

\begin{tabular}{|c|c|c|c|c|c|c|c|c|c|c|c|}
\hline & (1) & (2) & (3) & (4) & (5) & (6) & (7) & (8) & (9) & (10) & (11) \\
\hline & $\begin{array}{c}\text { Number of } \\
\text { observations }\end{array}$ & $\begin{array}{l}\text { Mean of } \\
\text { control }\end{array}$ & Aspirations & Knowledge & $\begin{array}{c}\text { Aspirations } \\
= \\
\text { Knowledge } \\
\text { (p-value) }\end{array}$ & $\begin{array}{c}\text { Aspirations } \\
\text { only } \\
\text { (T1) }\end{array}$ & $\begin{array}{c}\text { Knowledge } \\
\text { only } \\
\text { (T2) }\end{array}$ & $\begin{array}{c}\text { Aspirations } \\
+ \\
\text { Knowledge } \\
\text { (T3) }\end{array}$ & $\begin{array}{c}\mathrm{T} 1=\mathrm{T} 2 \\
=\mathrm{T} 3 \\
\text { (p-value) }\end{array}$ & $\begin{array}{l}\mathrm{T} 1=\mathrm{T} 3 \\
\text { (p-value) }\end{array}$ & $\begin{array}{l}\mathrm{T} 2=\mathrm{T} 3 \\
\text { (p-value) }\end{array}$ \\
\hline Owns a business (1=yes) & 2,464 & 0.743 & $\begin{array}{l}-0.008 \\
(0.020)\end{array}$ & $\begin{array}{c}0.009 \\
(0.020)\end{array}$ & 0.567 & $\begin{array}{l}-0.028 \\
(0.028)\end{array}$ & $\begin{array}{l}-0.011 \\
(0.030)\end{array}$ & $\begin{array}{c}0.001 \\
(0.028)\end{array}$ & 0.551 & 0.278 & 0.692 \\
\hline $\begin{array}{l}\text { Started a new business in the post } \\
\text { training period }\end{array}$ & 2,457 & 0.1 & $\begin{array}{l}0.016 \\
(0.013)\end{array}$ & $\begin{array}{r}0.005 \\
(0.013)\end{array}$ & 0.514 & $\begin{array}{l}0.028 \\
(0.018)\end{array}$ & $\begin{array}{r}0.016 \\
(0.015)\end{array}$ & $\begin{array}{l}0.021 \\
(0.018)\end{array}$ & 0.796 & 0.719 & 0.775 \\
\hline Value of business(es) today & 2,446 & 40,139 & $\begin{array}{l}-2,505 \\
(4,915)\end{array}$ & $\begin{array}{c}4,545 \\
(4,797)\end{array}$ & 0.292 & $\begin{array}{l}-2,488 \\
(7,108)\end{array}$ & $\begin{array}{c}4,561 \\
(6,293)\end{array}$ & $\begin{array}{c}2,039 \\
(7,057)\end{array}$ & 0.575 & 0.529 & 0.701 \\
\hline $\begin{array}{l}\text { Asset index (PCA of } 11 \text { household } \\
\text { goods) }\end{array}$ & 2,463 & -0.063 & $\begin{array}{l}0.004 \\
(0.105)\end{array}$ & $\begin{array}{r}0.026 \\
(0.103)\end{array}$ & 0.883 & $\begin{array}{l}-0.006 \\
(0.154)\end{array}$ & $\begin{array}{r}0.016 \\
(0.147)\end{array}$ & $\begin{array}{r}0.030 \\
(0.148)\end{array}$ & 0.970 & 0.806 & 0.922 \\
\hline
\end{tabular}

Notes: Each row (dependent variable) reports results from two separate regressions. The first regression result is in Columns (3) and (4) where the main independent variables are binary indicators of receiving aspirations or knowledge treatments (Aspirations $=\mathrm{T} 1$ or T3, and Knowledge $=\mathrm{T} 2$ or T3). The second regression is in Columns (6)-(9), with three treatments (T1, T2 and T3) as separate independent variables.

All regressions include a constant and dummies for the sampling strata. Robust standard errors clustered at the center level are reported in parenthesis. ${ }^{* * *}$ Significant at $1 \%$, ${ }^{* *}$ Significant at $5 \%,{ }^{*}$ Significant at 
Table A6: Impact on expenditures

\begin{tabular}{|c|c|c|c|c|c|c|c|c|c|c|c|}
\hline & (1) & (2) & (3) & (4) & $(5)$ & (6) & (7) & (8) & (9) & $(10)$ & $(11)$ \\
\hline & $\begin{array}{l}\text { Number of } \\
\text { observations }\end{array}$ & $\begin{array}{l}\text { Mean of } \\
\text { control }\end{array}$ & Aspirations & Knowledge & $\begin{array}{c}\text { Aspirations } \\
\quad= \\
\text { Knowledge } \\
\text { (p-value) }\end{array}$ & $\begin{array}{c}\text { Aspirations } \\
\text { only } \\
\text { (T1) }\end{array}$ & $\begin{array}{c}\text { Knowledge } \\
\text { only } \\
\text { (T2) }\end{array}$ & $\begin{array}{c}\text { Aspirations } \\
+ \\
\text { Knowledge } \\
\text { (T3) }\end{array}$ & $\begin{array}{c}\mathrm{T} 1=\mathrm{T} 2= \\
\mathrm{T} 3 \\
\text { (p-value) }\end{array}$ & $\begin{array}{l}\mathrm{T} 1=\mathrm{T} 3 \\
\text { (p-value) }\end{array}$ & $\begin{array}{l}\mathrm{T} 2=\mathrm{T} 3 \\
\text { (p-value) }\end{array}$ \\
\hline $\begin{array}{l}\text { Total monthly household } \\
\text { expenditures (pesos, monthly) }\end{array}$ & 2,376 & 13,221 & $\begin{array}{l}-659 \\
(602)\end{array}$ & $\begin{array}{c}422 \\
(567)\end{array}$ & 0.202 & $\begin{array}{l}-192 \\
(848)\end{array}$ & $\begin{array}{c}871 \\
(800)\end{array}$ & $\begin{array}{l}-225 \\
(802)\end{array}$ & 0.329 & 0.968 & 0.181 \\
\hline $\begin{array}{l}\text { Food consumed outside home } \\
\text { (pesos, monthly) }\end{array}$ & 2,463 & 89.8 & $\begin{array}{l}-11.56 \\
(13.1)\end{array}$ & $\begin{array}{c}0.70 \\
(13.1)\end{array}$ & 0.483 & $\begin{array}{l}-14.6 \\
(18.2)\end{array}$ & $\begin{array}{l}-2.28 \\
(20.8)\end{array}$ & $\begin{array}{l}-10.93 \\
(19.6)\end{array}$ & 0.775 & 0.804 & 0.631 \\
\hline $\begin{array}{l}\text { Temptation goods - alcohol, } \\
\text { tobacco, gambling, etc. (pesos, }\end{array}$ & 2,446 & 593 & $\begin{array}{l}-47.36 \\
(63.2)\end{array}$ & $\begin{array}{c}0.8 \\
(57.4)\end{array}$ & 0.548 & $\begin{array}{l}-98.2 \\
(75.6)\end{array}$ & $\begin{array}{l}-48.3 \\
(84.3)\end{array}$ & $\begin{array}{l}-47.9 \\
(90.4)\end{array}$ & 0.717 & 0.491 & 0.996 \\
\hline $\begin{array}{l}\text { Celebrations - fiesta, birthday, } \\
\text { wedding etc. (pesos, six-monthly) }\end{array}$ & 2,461 & 2,494 & $\begin{array}{l}8.30 \\
(261)\end{array}$ & $\begin{array}{c}289 \\
(252)\end{array}$ & 0.458 & $\begin{array}{l}-75.7 \\
(357)\end{array}$ & $\begin{array}{l}208.3 \\
(374)\end{array}$ & $\begin{array}{l}295.9 \\
(347)\end{array}$ & 0.547 & 0.292 & 0.818 \\
\hline $\begin{array}{l}\text { Durable goods - clothing, } \\
\text { appliances, furniture, etc. (pesos, six- }\end{array}$ & 2,455 & 1,481 & $\begin{array}{l}-20.7 \\
(183)\end{array}$ & $\begin{array}{c}217 \\
(165)\end{array}$ & 0.336 & $\begin{array}{l}30.7 \\
(210)\end{array}$ & $\begin{array}{l}266.4 \\
(242)\end{array}$ & $\begin{array}{l}197.0 \\
(245)\end{array}$ & 0.570 & 0.470 & 0.804 \\
\hline Education (pesos, six-monthly) & 2,457 & 1,805 & $\begin{array}{c}40 \\
(140)\end{array}$ & $\begin{array}{l}-149 \\
(139)\end{array}$ & 0.273 & $\begin{array}{c}-132.1 \\
(202)\end{array}$ & $\begin{array}{c}-315.5 \\
(218)\end{array}$ & $\begin{array}{c}-111.8 \\
(220)\end{array}$ & 0.473 & 0.903 & 0.276 \\
\hline
\end{tabular}

Notes: Each row (dependent variable) reports results from two separate regressions. The first regression result is in Columns (3) and (4) where the main independent variables are binary indicators of receiving aspirations or knowledge treatments (Aspirations $=\mathrm{T} 1$ or T3, and Knowledge $=\mathrm{T} 2$ or T3). The second reoression is in Columns (6)-(9), with three treatments (T1, T2 and T3) as separate independent variables. All regressions include a constant and dummies for the sampling strata. Robust standard errors clustered at the center level are reported in parenthesis. *** Significant at $1 \%, * *$ Significant at $5 \%$, * Significant at $10 \%$. 
Table A7: Impact on locus of control and time preferences, long-form

\begin{tabular}{|c|c|c|c|c|c|c|c|c|}
\hline & (1) & (2) & (3) & (4) & (5) & (6) & (7) & (8) \\
\hline & $\begin{array}{l}\text { Number of } \\
\text { observations }\end{array}$ & $\begin{array}{c}\text { Mean of } \\
\text { control }\end{array}$ & $\begin{array}{c}\text { Aspirations } \\
\text { only } \\
\text { (T1) }\end{array}$ & $\begin{array}{c}\text { Knowledge } \\
\text { only } \\
\text { (T2) }\end{array}$ & $\begin{array}{c}\text { Aspirations } \\
+ \\
\text { Knowledge } \\
\text { (T3) }\end{array}$ & $\begin{array}{c}\mathrm{T} 1=\mathrm{T} 2= \\
\mathrm{T} 3 \\
\text { (p-value) }\end{array}$ & $\begin{array}{c}\mathrm{T} 1=\mathrm{T} 3 \\
\text { (p-value) }\end{array}$ & $\begin{array}{l}\mathrm{T} 2=\mathrm{T} 3 \\
\text { (p-value) }\end{array}$ \\
\hline Locus of control & 2,463 & 41.8 & $\begin{array}{l}-1.17 * * \\
(0.475)\end{array}$ & $\begin{array}{c}-0.969^{* *} \\
(0.418)\end{array}$ & $\begin{array}{c}-1.37 * * * \\
(0.406)\end{array}$ & 0.649 & 0.661 & 0.353 \\
\hline Present bias (fraction of choices) & 2,464 & 0.134 & $\begin{array}{c}0.010 \\
(0.018)\end{array}$ & $\begin{array}{l}-0.014 \\
(0.017)\end{array}$ & $\begin{array}{l}-0.005 \\
(0.016)\end{array}$ & 0.388 & 0.340 & 0.590 \\
\hline
\end{tabular}

Notes: Each row (dependent variable) reports results from the regression of individual binary indicators for the three treatments (T1, T2 or T3). All regressions include a constant and dummies for the sampling strata. Robust standard errors clustered at the center level are reported in parenthesis. *** Significant at $1 \%$, ** Significant at $5 \%$, $*$ Significant at $10 \%$. 


\section{Appendix II: Contents of the Two Training Programs}

Often the content of training programs is a black box, making it difficult to compare across studies. We provide session-by-session details here to enable the reader to more clearly see what was emphasized in the two training programs.

\section{Knowledge Training}

\section{Session 1: Calculating Your Net Worth Part 1}

Session goal: introduce clients to a structured framework for understanding their financial status, and advise clients to save more as it will add to their assets and increase their net worth.

This session introduces the clients to the general notion of Assets, Liabilities and Net worth by asking the clients to write down their assets and liabilities and estimating their total values. Assets were defined as 'something you own that you could resell'; Liabilities as 'something you owe'; and Net Worth as 'how much is left after deducting your liability from your assets'. This session emphasized that one could increase her net worth by saving and that the PALFSI Flexible Savings Account is one of their options to accumulate savings.

\section{Session 2: Calculating Your Net Worth and Understanding PALFSI's Flexible Savings Account}

Session goal: teach clients how to calculate their net worth by methodically estimating the value of each asset and liability.

This session is a continuation of the previous session. The clients were asked to assign values to their assets and liabilities which they listed in the previous session. They were then asked to subtract the value of their assets from the liabilities to come up with their net worth.

In this session the advantages and the disadvantages of formal and informal savings were also discussed and the clients were given the handout about the comparison. In addition the PALFSI Flexible Savings Account Fact Sheet handout was also distributed so that the client will better understand the PALFSI Flexible Savings Account. The clients were also asked to create an inventory of their assets and liabilities by filling out the handout Asset and Liabilities calculation.

\section{Session 3: Calculating Savings}

Session goal: introduce clients to the concept that saving a little bit everyday can turn into a lot of money, to the idea that saving in a bank account is preferable to saving at home because it rewards people with interest, and to simple math on savings accumulation.

The interest rate was introduced as 'a financial reward for saving in a bank (or a formal institution like PALFSI) or a cost for taking out loan. Saving at home vs. saving in an interest-bearing account was also discussed in this session. The clients were given the 'Computing for Savings' handout. It was stressed that forgoing with some typical temptation goods (like 'Jueteng' [a local lottery which is illegal], cigarettes, alcoholic beverages and soft drinks) can be a source of money for savings. Saving a little a day will accumulate savings if done regularly, was also emphasized in this session.

\section{Session 4: Calculating Simple Long Term Financial Goals}


Session goal: create knowledge and awareness of long-term expenses like retirement, education and marriage, and of the importance of saving a little bit everyday to help reach these expenses.

The clients were given a copy of the 'Simple Long Term Financial Goals Calculator' handout. As an example, retirement was discussed as a long term financial goal. They were asked to compute for the amount they should save daily or weekly to successfully retire. It was emphasized in this session that if they save in an interest bearing account they would have to set aside smaller amounts daily or weekly for their long term financial goals such as retirement, education etc., compared to saving at home. The clients were advised to save more on PALFSI savings account where their savings can grow.

\section{Session 5: Introduction to Budgets}

Session goal: Introduce clients to the concept of budgeting, help them understand where they are spending their money, their flow of income, and where opportunities lie to cut down on spending and increase savings.

Clients were introduced to the concept of Budgeting. They were taught how to compare their earnings from their expenses using the Budget Table Handout. Clients were asked to identify where they could cut down on certain spending and translate it into savings. They were also asked to check if their expenses are greater than their income and what expenses they could forgo to at least equalize their income and expenses or better yet cut on expenses to save. It was emphasized in this session that in order to save effectively they should first set aside a portion of their income for savings as opposed to spending first and save whatever is left from their income. Setting aside an amount from the income will make sure that they can save and PALFSI Flexible Savings Account is a place to accumulate these savings.

\section{Session 6: Budgets and Savings}

Session goal: Delve deeper into the concept of budgeting introduced in previous session, and help identify opportunities to cut down on spending and increase savings.

This session is the second part of the topics on budget. The clients were asked to fill out the Last Week's Budget and the Next Weeks' Budget Handout. They were asked to recall all their expenses in the past week to help them think about their expenses for the coming week. It was emphasized in this exercise that knowing about where they spent on in the last week will help them plan for the succeeding week and make adjustments on their expenses so that they can save. This exercise will help them identify opportunities to cut down on expenses to increase savings.

\section{Session 7: Budgets Part 3}

Session goal: Continue to learn more about budgeting, and help clients understand how hindsight and foresight can differ.

This is part 3 of the budgeting sessions. The loan officers reviewed the concept of budgeting as a 'financial plan for a long term and short term future'. The clients were asked to fill out another Last Week's Budget Handout and ask them to compare the Next Week's Budget handout they filled out in the preceding week. The disparities between the two were highlighted as the difference between hindsight and foresight. 
The difference between hindsight and foresight was emphasized in this session. It was also emphasized that if their carefully plan and practice more on budgeting they could have a better control of their future expenses and this would help them identify opportunities for saving.

\section{Session 8. Financial Knowledge Quiz}

Session goal: Reinforce learning of first seven sessions and review contents.

In this session, the clients were asked to take a simple quiz about what they learned in the previous 7 session as a review. The loan officers clarified question with regards to the concepts which were introduced in the previous sessions. It also discusses savings in general and savings at PALFSI through the flexible savings accounts to help clients better understand the benefits of savings.

\section{Aspirations Training}

\section{Session 1: Overcoming Limiting Beliefs}

Session goal: intended to teach clients that personal obstacles can be overcome through a positive mindset, an optimistic outlook, and a willingness to try again. The goal is to boost each individual client's sense of self and confidence in overcoming obstacles in life.

Participants were paired and were asked to stack up Styrofoam cups (In the form of a pyramid). This was done 3 times per client. In the first and second try, the cups were scattered on the table, but on the 3rd try each client were told that they can pre-arrange the cups in a way that will make it easier for them to stack it later to improve their time.

The learning emphasized was 'positive mindset and confidence can help overcome personal obstacles and planning ahead would help them better overcome obstacles. It was emphasized that savings through the PALFSI Flexible Capital Build Up is a way to prepare for emergencies and build up capital for investments.

\section{Session 2: Dream Collage}

Session goal: intended to help clients to focus on their long term goals and organize their thoughts about how they can reach these goals.

Participants were asked to make a Dream Collage by cutting out pictures from newspapers or draw representations of what they want to have or achieve in the future and paste it in an illustration board. They were then asked to make a list of the dreams in the Dream List handout from the Dream Collage they made. They also presented their Dream Collage to the group. At the end of the session the clients were told to bring home their dream map and post it on their wall to remind them of what they should work towards.

The learning emphasized was to focus on their long term goals and organize their thoughts about how they can reach these goals. It was also emphasized that achieving long term goals requires planning and financial preparations and PALFSI's Flexible Savings Capital Build Up is a good place to save one's money.

\section{Session 3: Dream Timeline and Financial Matrix}

Session goal: intended to help clients organize their financial plans and structure their approaches towards reaching their goals. 
Based on their Dream list from the previous session, the clients were asked to create a Dream Goal by selecting a business goal that they could achieve in 6 months to 1 year. They were then asked to articulate this business goal by filling out clear goals. They have to make their goal measurable, assign dates on when they want to start and achieve their goals, and visualize it.

They were also asked to fill in the Dream Map handout by sorting their dreams as to whether the dreams are related to their business or family by writing the dreams above or below the ladder. It was also emphasized that the PALFSI Flexible Savings Account can help clients work towards their financial goals and meet the plans detailed in the Dream Map and Financial Matrix.

\section{Session 4: Delaying Gratification "Marshmallow" Experiment}

Session goal: intended to motivate clients to avoid immediate gratification that can be costly to long term gratification and inspire clients to think longer into the future.

The clients were shown a video presentation, the "Marshmallow" experiment which was dubbed in Filipino. In this session it was emphasized that delaying gratification in the short term will create opportunities in the long term. Like forgoing with purchasing of a new TV set and investing the money instead in their business will give them long term benefits or opportunities in the future. The movie was a tool to inspire clients to think farther into the future. It was also a tool to bring across the idea that the values of patience, self-discipline and focus will help them achieve their long term goals.

\section{Session 5: Overcoming Limiting Beliefs II}

Session goal: intended to teach clients that personal obstacles can be overcome through a positive mindset, an optimistic outlook, and a willingness to try again.

This session is the same as Session 1 but instead of 10 cups they were asked to use 15 cups. It was emphasized in this session that situations may change, oftentimes beyond their control, but they could always adjust to the new situation by changing their negative attitudes to positive ones. By saving in the PALFSI Flexible Savings Account they could also prepare for any unforeseen events in the future.

\section{Session 6: Understanding Your "Why"}

Session goal: encourage clients to think deeper about their future business goals and inspire a more future oriented mindset.

The clients were asked to fill out the Understanding Your "Why" Handout by identifying one of their business goals. They were then asked to pair with another group mate and discuss why the goal was important to them. They were asked to visualize their dream. It was emphasized in this exercise that if they want to pursue their goal they should be persistent in achieving it and that they should have a more future oriented mindset.

\section{Session 7: Review of Dream Timeline and Financial Matrix}

Session goal: bring together the lessons learned from previous trainings and inspire the clients to move forward with their dreams. 
This is a review of Sessions 1, 3, and 6 with the objective to inspire the clients to move on with achieving their dreams. Believing in oneself was also emphasized in this session. PALFSI Flexible Savings Account was again mentioned as a way to help clients save money to help them in their future plans.

\section{Session 8: Rich Mindset}

Session goal: intended to finalize the aspirations training with a discussion of how to think positively and powerfully about one's finances. The take away from this session is that positive thoughts lead to positive results. Furthermore, if a poor man saves his money and plans for the future, he can turn into a rich man.

For this session, the loan officers discussed the statements in the Rich Mindset Handout while asking the clients to give examples to the group when they acted with a rich mindset or a poor mindset. When they give examples of when they acted with a poor mindset the loan officer they were asked how to change it into a rich mindset. It was emphasized in this session how positive thinking can lead to positive results. In addition, a poor man saving money can turn into a rich man. For the clients, saving in PALFSI Flexible Savings Account is a part of the rich mindset.

\section{Exhibit A1. The Aspirations Training Stressed Setting Big Goals}

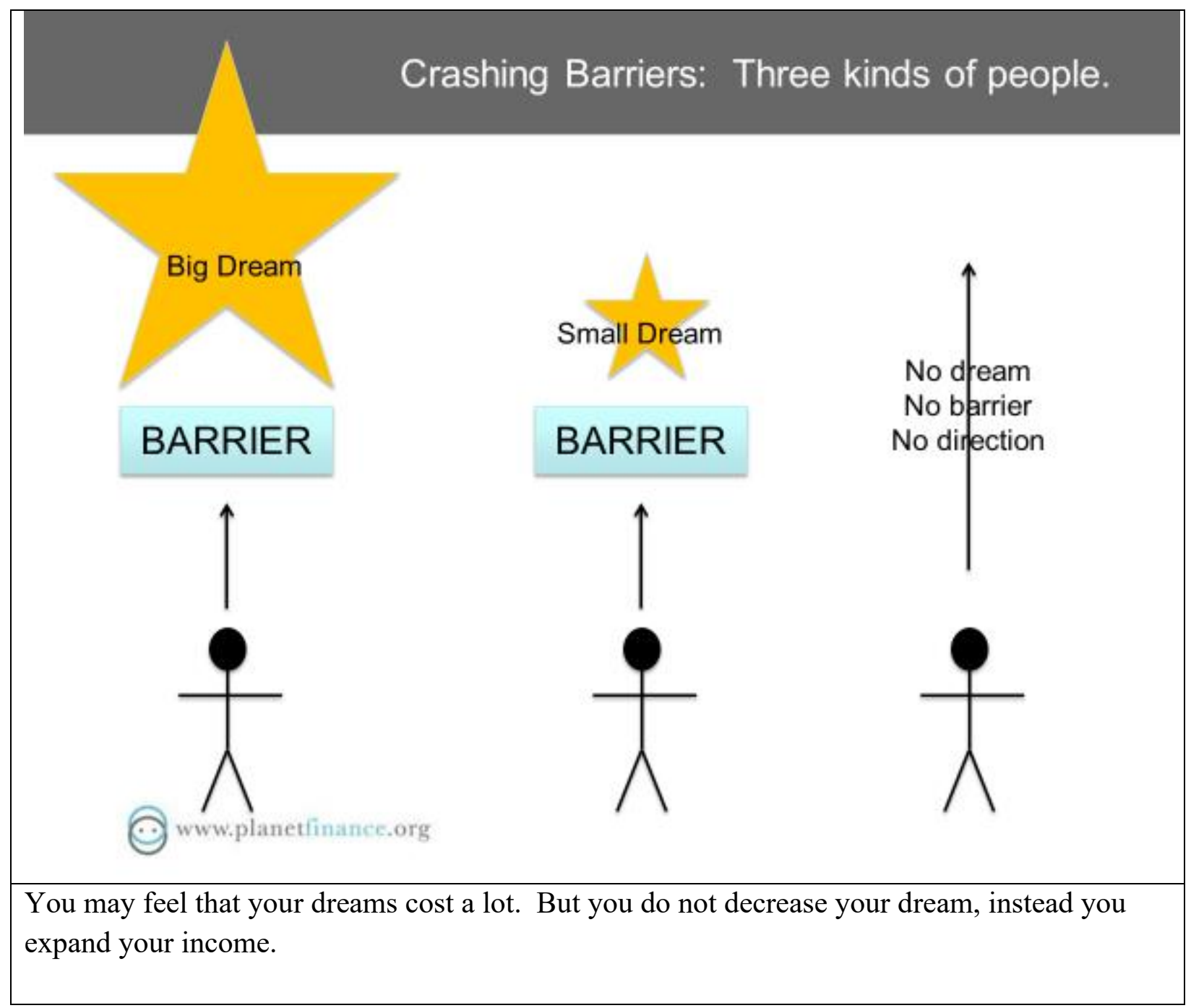




\section{Anecdote:}

Ask a fresh graduate what kind of home he wants: often the answers are: Big house, with garage, three bedrooms, big yard, with maybe a swimming pool. This person has no income, yet he dreams big!

Ask a working person what kind of home he wants: often the answer will be, "ung simple lang po na kaya ng pag-ibig fund".

1. A person without a dream does not have any barriers. His future is also uncertain because he has no direction.

2. A person with a small dream will always only see barriers blocking his way into achieving his dreams.

3. A person with a big dream will see his dream and not his barrier. Because the barrier is too small compared to his dream.

\section{Appendix III: Measurement}

\section{A. Survey Questions Related to Training Retention}

\section{Aspirations training related questions}

1) Which of the following is/are examples of "Limiting Beliefs"?
a) I can't sing well, but if I try or go to singing lessons, I can improve my ability
b) I did not finish my studies so I will never be rich
c) I am a housewife, but I can also be an entrepreneur if I want to
d) All of the above
e) Other (specify)
f) Don't know

2) What is a "Dream Collage"?
a) A collection of images of goals you wish to experience in reality
b) A tool designed to help you visualize your dreams
c) A tool to help you create a picture of what you want
d) All of the above
e) Other (specify)
f) Don't know

3) What is a "Dream Timeline"?

a) A tool that can help you organize your dreams in a structured and a realistic framework 
b) A collection of images of goals you wish to experience in reality

c) A list of all upcoming incomes and expenditures

d) All of the above

e) Other (specify)

f) Don't know

\section{Knowledge training related questions}

1) What is a budget?

a) A tool to calculate future loan payments

b) A tool to compare how much you earn to how much you spend

c) A tool to calculate interest on your loan

d) All of the above

e) Other (specify)

f) Don't know

2) What are assets?

a) Savings minus loans at PALFSI

b) How much you own that you could resell

c) How much you owe

d) All of the above

e) Other (specify)

f) Don't know

3) What are liabilities?
a) Savings minus loans at PALFSI
b) How much you own that you could resell
c) How much you owe
d) All of the above
e) Other (specify)
f) Don't know

4) What does net worth mean?
a) The amount you owe
b) How much you own minus how much you owe
c) The money in your bank account
d) All of the above
e) Other (specify)
f) Don't know

5) What is an interest rate? 
a) Monthly fees to maintain a bank account

b) How much you own that you could resell

c) A financial reward for saving with the bank or an extra cost for taking out a loan

d) All of the above

e) Other (specify)

f) Don't know

\section{B. Locus of Control}

For each of the 7 items, the following statements are read to the respondent. Then they are asked to respond to what extent they agree or disagree using a 7-point scale: $1=$ Strongly disagree, $2=$ Moderately disagree, $3=$ Slightly disagree, $4=$ Neutral $/$ neither disagree nor agree, $5=$ Slightly agree, $6=$ Moderately agree, $7=$ Strongly agree.

1) Saving and careful investing is a key factor in becoming rich

2) Whether or not I get to become wealthy depends mostly on my ability

3) In the long-run, people who take very good care of their finances stay wealthy

4) If I become poor, it's usually my own fault

5) I am usually able to protect my personal interests

6) When I get what I want, it's usually because I worked hard for it

7) My life is determined by my own actions

\section{Time Preferences and Present Bias}

We measure present bias using by asking individuals to make hypothetical choices between different money amounts tomorrow versus in one month early in the survey, and in two months versus three months later in the survey and seeing whether there are preference reversals (see modules below)

Respondents are given 20 tokens each worth 20 pesos ( 400 pesos total) and asked to allocate tokens to the two time periods. To incentivize respondents to allocate tokens honestly, they were told that a randomly chosen respondent's allocation will be implemented after all the surveys have been completed. The interest rate is held constant in both time periods $(10 \%, 25 \%, 50 \%, 75 \%, 100 \%)$. For a given interest rate, we consider a choice present biased when respondents allocated more to the nearer period when choosing between tomorrow and one month versus tomorrow compared to when choosing two months from tomorrow versus three months from tomorrow. 


\begin{tabular}{|c|c|c|c|}
\hline \multicolumn{4}{|c|}{$\begin{array}{l}\text { Surveyor instructions: Let the respondent rearrange tokens as many times as he/she likes. Write down the final answer } \\
\text { here and on the index card for each question }\end{array}$} \\
\hline 1 & $\begin{array}{l}\text { Tokens that you redeem tomorrow are worth } 20 \text { pesos each. Tokens that } \\
\text { you redeem one month from tomorrow are worth } 22 \text { pesos each. How } \\
\text { many tokens would you like to redeem tomorrow, and how many in one } \\
\text { month? }\end{array}$ & 20 pesos & Tokens in one month \\
\hline 2 & $\begin{array}{l}\text { Tokens that you redeem tomorrow are worth } 20 \text { pesos each. Tokens that } \\
\text { you redeem one month from tomorrow are worth } 25 \text { pesos each. How } \\
\text { many tokens would you like to redeem tomorrow, and how many in one } \\
\text { month? }\end{array}$ & $\begin{array}{c}20 \text { pesos } \\
\text { Tokens tomorrow }\end{array}$ & Tokens in one month \\
\hline 3 & $\begin{array}{l}\text { Tokens that you redeem tomorrow are worth } 20 \text { pesos each. Tokens that } \\
\text { you redeem one month from tomorrow are worth } 30 \text { pesos each. How } \\
\text { many tokens would you like to redeem tomorrow, and how many in one } \\
\text { month? }\end{array}$ & 20 pesos & Tokens in one month \\
\hline 4 & $\begin{array}{l}\text { Tokens that you redeem tomorrow are worth } 20 \text { pesos each. Tokens that } \\
\text { you redeem one month from tomorrow are worth } 35 \text { pesos each. How } \\
\text { many tokens would you like to redeem tomorrow, and how many in one } \\
\text { month? }\end{array}$ & 20 pesos & Tokens in one month \\
\hline 5 & $\begin{array}{l}\text { Tokens that you redeem tomorrow are worth } 20 \text { pesos each. Tokens that } \\
\text { you redeem one month from tomorrow are worth } 40 \text { pesos each. How } \\
\text { many tokens would you like to redeem tomorrow, and how many in one } \\
\text { month? }\end{array}$ & Tokens tomorrow & Tokens in one month \\
\hline
\end{tabular}

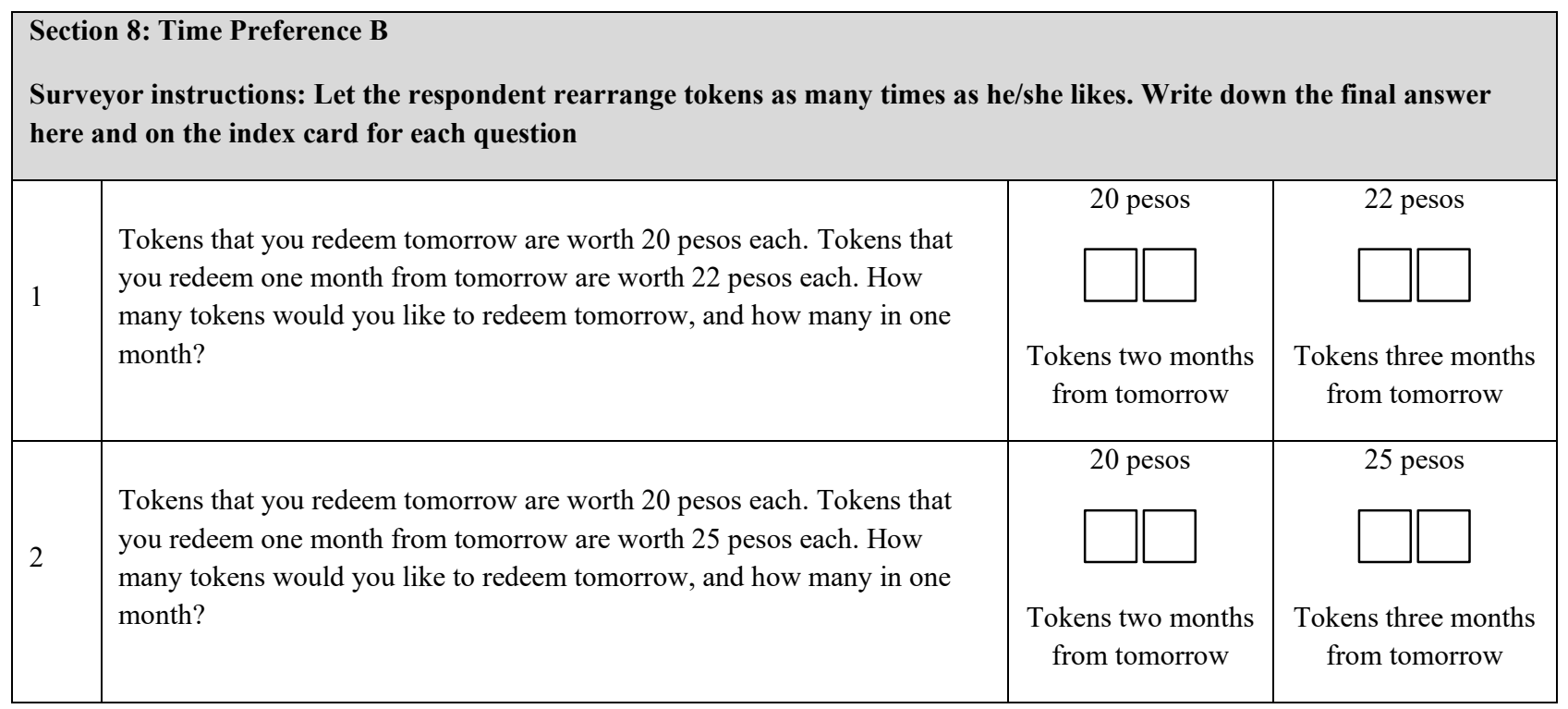




\begin{tabular}{|l|l|l|l|}
\hline 3 & $\begin{array}{l}\text { Tokens that you redeem tomorrow are worth } 20 \text { pesos each. Tokens that } \\
\text { you redeem one month from tomorrow are worth } 30 \text { pesos each. How } \\
\text { many tokens would you like to redeem tomorrow, and how many in one } \\
\text { month? }\end{array}$ & $\begin{array}{l}\text { Tou redeem one month from tomorrow are worth } 35 \text { pesos each. How } \\
\text { many tokens would you like to redeem tomorrow, and how many in one } \\
\text { month? }\end{array}$ & $\begin{array}{l}\text { Tokens two months } \\
\text { from tomorrow }\end{array}$ \\
\hline 5 & $\begin{array}{l}\text { Tokens three months } \\
\text { from tomorrow } \\
\text { you redeem one month from tomorrow are worth } 40 \text { pesos each. How } \\
\text { many tokens would you like to redeem tomorrow, and how many in one } \\
\text { month? }\end{array}$ & \begin{tabular}{|l|l|} 
Tokens two months \\
from tomorrow
\end{tabular} \\
\hline 5
\end{tabular}

